\title{
Assessment of the Geotouristic Values of Devil's Town, Serbia
}

\author{
Danijela Vukoičić ${ }^{1}$, Danica Srećković- Batoćanin ${ }^{2}$, Aleksandar Valjarević ${ }^{3}$, Dušan Ristić ${ }^{1}$, \\ Milena Nikolić ${ }^{1}$ and Dragana Valjarević ${ }^{4}$ \\ ${ }^{1}$ University of Priština in Kosovska Mitrovica, Faculty of Sciences and Mathematics, Department of Geography, Lole Ribara 29,38220 Kosovska Mitrovica
2 University of Belgrade, Faculty of Mining and Geology, Đušina 7, 11000 Belgrade, Serbia
${ }^{3}$ University of Belgrade, Faculty of Geography, Department of Geospatial and Environmental Science Studentski trg 3/III, 11000 Belgrade, Serbia
${ }^{4}$ University of Pristina in Kosovska Mitrovica, Faculty of Sciences and Mathematics, Department of Mathematics, Lole Ribara 29, 38220 Kosovska Mitrovica
( ${ }^{*}$ corresponding author: dragana.valjarevic@pr.ac.rs)
}

doi: $10.4154 / g c .2021 .11$

Article history:

Manuscript received May 19, 2020

Revised manuscript accepted March 22, 2021

Available online June 30, 2021

\begin{abstract}
Serbia is a country rich in geoheritage with eighty geomorphological sites now under protection. Although a canyon, the site of Devil's Town is a unique geomorphological site in Serbia and deserves special attention. The geotouristic values of Devil's Town were assessed based on the analysis of its present state and comparison with three similar and nearby geosites on the Balkan Pennisula (the Sand Pyramids in Bosnia and Herzegovina and the Stob and Melnik Earth pyramids in Bulgaria). The assessment was performed using a 'modified geosite assessment model' (M-GAM), which includes estimation of the main indicators and sub-indicators. Devil's Town has an average level of major and additional values. Indicators show that this geosite has great tourist, scientific and aesthetic value, as well as enough space for improving the ecological and functional values, as a basis for the development of tourism. Devil's Town displays a higher touristic value than the Sand pyramids and slightly lower than the Stob pyramids. However, in comparison with the Melnik Earth pyramids in Bulgaria, its touristic value is significantly lower. This study could serve as a guide for managing development strategies concerning decision-making and engagement in tourism of the analysed geosite, addressing the needs of modern tourists.
\end{abstract}

Keywords: Geotourism, Geosite assessment M-GAM, Comparative analysis, Devil's Town, Sand Pyramids, Stob Pyramids, Melnik Pyramids, Serbia
However, the geotourism potential and geoturist values of this geosite remain partially hidden.

The promotion of geological and geomorphological heritage is growing in importance when it comes to cultural tourism and landscape valorisation as thematic excursions and itineraries (REYNARD, 2009). The first official definition of geotourism was given by Thomas Hose, $(1995,1996)$, and later reformulated (HOSE, 2000). Geotourism, as a geoscience-based tourist activity, is a process of recognizing and giving a wider meaning to geoheritage objects in order to preserve them more effectively (HOSE, 2005a). A straightforward definition was given by JOYCE (2006), who defines geotourism as a situation where "people go to certain places to observe one or more aspects of geology and geomorphology and learn about them." The definition of geotourism given by GRAY (2008), takes a view on the need for geoconservation; "Tourism is based on geological and geomorphological resources of an area that attempts to minimize the (negative) impact of this tourism through geoconservation and sustainable management". Under geoconservation, BUREK \& PROSSER (2008) include active site management in order to preserve the original state and prevent any changes. Geoconservation measures in combination with the promotion of tourism are the most important elements of geotourism (HOSE, 2005b). SADRY (2009) states that geotourism is in fact knowledge-based tourism, interdisciplinary integration of the tourism industry with conservation and interpretation of the attributes, abiotic in nature, in order to bring the geosite closer to the general public. NEWSOME \& DOWLING (2010) have come to the conclusion that geotourism promotes tourism at geosites as well as the conservation of geodiversity and understanding of the geosciences by means of respect and understanding (learning). The latest definition of modern geodominant forms, including ground-water seepages and scars). 
tourism was developed by HOSE \& VASILJEVIĆ (2012): "Providing interpretative content and services at geosites, geomorphological sites and the surrounding topography, together with related in-situ and ex-situ artifacts, in order to conserve them, improve their appreciation, education and scientific work both [by, and] for, the present and the future generations."

The basic principles of the fundamental importance for geotourism are: geological basis, sustainability, geointerpretation, benefit to the local community and tourist satisfaction (DOWLING, 2011). The economic perspective should also be taken into account. Geosites as a basis of geotourism development contribute to both the original and the additional tourist offer (PRALONG, 2006). In the context of geotourism, geoheritage provides the original offer. The additional offer consists of the infrastructure, goods and services offered to tourists in order to complete, improve and facilitate their visit. These can be informative and interpretative boards, the construction of paths and lifts to hardto-reach places, or the organization and training of the guides (PRALONG \& REYNARD, 2005; REYNARD, 2008). Tourist exploitation of geography can have a negative impact on Earth systems (NEWSOME \& DOWLING, 2006; HOSE, 2008; HOSE et al., 2011; HOSE \& VASILJEVIĆ, 2012) which can lead to degradation and an increase in the vulnerability of the geodiversity. Thus, it is necessary to create such an offer that will bring geological and geomorphological knowledge and scientific achievements to all visitors, as well as enabling the undisturbed and improved development of tourist activities.

Numerous methods which were used for evaluating geosites were focused on the scientific value of the geosite, and only later included additional values (GRANDGIRARD \& SZEPESI, 1997; BRAGA, 2002; BRUSCHI \& CENDRERO, 2005; PANIZZA \& PIACENTE, 2003; CORATZA \& GIUSTI, 2005; GRAY, 2013; PRALONG, 2005; BRILHA, 2005; REYNARD, 2009; REYNARD et al., 2016; REYNARD \& BRILHA., 2018; PEREIRA et al., 2007; REIS \& HENRIQUES, 2009; TOMIĆ, 2011;
VUJIČIĆ et al., 2011; ROCHA et al., 2014). Evaluation of geodiversities and geoheritage in Serbia was carried out mainly using a descriptive method until the last decade of the 20th century when eminent experts from all geodisciplines established and proposed scientific and educational criteria for geoheritage evaluation, while planning the protection of natural areas (NOJKOVIĆ \& MIJOVIĆ, 1998; MIJOVIĆ \& MILJANOVIĆ, 1999). In the last few years, a lot of authors from Serbia have contributed to the foundation of modern thought on the need and significance of protecting and promoting geodiversity and geoheritage (LJEŠEVIĆ, 2002; MIJOVIĆ, 2002; MIJOVIĆ et al., 2005; DJUROVIĆ \& MIJOVIĆ, 2006; BELIJ, 2007; 2008; 2009; VUJIČIĆ et al., 2011; VASILJEVIĆ et al., 2011; TOMIĆ, 2011; BOŽIĆ \& TOMIĆ, 2015; BOŠKOV et al., 2015; TOMIĆ \& BOŽIĆ, 2016; ANTIĆ \& TOMIĆ, 2017; VALJAREVIĆ et al., 2017; VUKOIČIĆ et al., 2018; ANTIĆ et al., 2019; ANTIĆ et al., 2020).

Serbia has the potential for an increase in geotourism but is obviously lagging behind countries with developed tourism. Hence, the main goal of this study is to assess the geotouristic values of Devil's Town and its comparison with the three similarly featured and nearby geosites in the Balkans (Sand Pyramids in Bosnia and Herzegovina and Stob and Melnik Earth pyramids in Bulgaria) by applying the M-GAM model. The results obtained should point to the potential advantages and disadvantages in these analyzed localities as well as to the main future tasks of management during the planning and development of a tourist offer aiming to adjust these to attractive tourist destinations.

\section{MATERIAL AND METHODS}

\subsection{Study area}

Devil's Town spatially belongs to the municipality of Kuršumlija, and the village of Djake on Radan Mountain (central part of Southern Serbia). It covers an area of 8.31 ha, at an altitude of 660 - $796 \mathrm{~m}$ a.s.l. The Devil's Town is located $290 \mathrm{~km}$ from Belgrade,

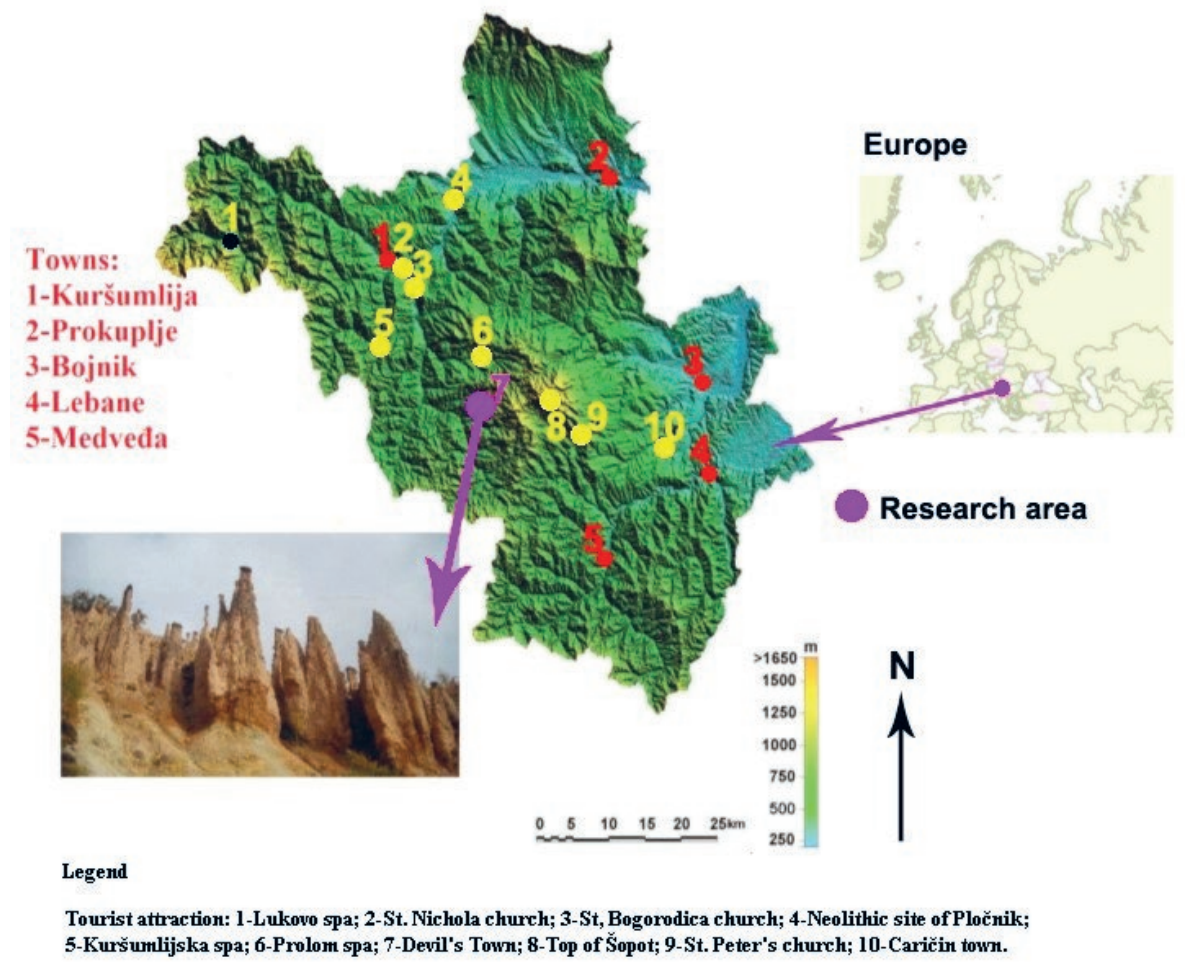

Figure 1. Location map of Devil's Town (Source of hypsometry: CGIAR Consortium for Spatial Information, 2017). 
$29 \mathrm{~km}$ from Kuršumlija, and $9 \mathrm{~km}$ from the state road IB category no. 35 Niš-Priština. Beside this state road, there is also the Niš Prokuplje - Kosovo Polje railway. The closest airports are Slatina in Priština (57 km) and the airport in Niš (92 km). Prolom Banja, which is one of the most visited spas of great touristic value in Serbia (TOMIĆ \& KOŠIĆ, 2020), is located nearby, $28 \mathrm{~km}$ from Devil's Town. These two tourist-attractive destinations are connected by a well-built hiking trail. Parking for vehicles is $850 \mathrm{~m}$ away from Devil's Town, and the hiking trail leads to the top of the erosive fountain with a viewpoint that allows sightseeing and photography of the stone formations. At the beginning of the hiking trail, several ethno-style mountain lodges were built, one housing a restaurant with food prepared in the traditional Serbian style and an art galery where the photo-contest "Devil's Town" is traditionally held in May each year (Fig. 1).

Regarding geology, Devil's Town is located within the Lece volcanic complex, which is one of the largest Tertiary volcanic provinces in Serbia. It is, (observing the geotectonic setting), situated along the boundary between the Serbo-Macedonian mass (SMM) to the east and the Eastern Vardar zone to the west (Fig. 2). These two units are delineated by the Propolac-Medvedja and Tupala dislocation (STAJEVIĆ, 2004). The former unit has been interpreted as part of the deformed margin of the Eurasia continental plate, while the latter is considered a remnant of the vast Tethys Ocean (e.g. SCHMID et al., 2008).

According to the generally accepted explanation, the volcanic complex of Lece was formed in response to the Dinaride collapse. Magmatism took place along dextral strike-slip faults that resulted in transpressive crustal shortening and collision of the SMM as a part of the European plate within a short time frame, from about 33 to $31 \mathrm{Ma}$ (DRAGIĆ et al., 2014; TOSDAL, 2012).

The unique geomorphological phenomenon in Serbia contains about 202 stone formations formed on steep slopes of two deep, parallel cut gullies. The formations are of different shapes and sizes. The oldest ones are the highest, up to $17 \mathrm{~m}$ high, and they are placed at about $670 \mathrm{~m}$ a.s.1., while smaller forms are up to $2 \mathrm{~m}$ high and are placed at about 680 to $700 \mathrm{~m}$ a.s.l. Today, it is very easy to find videos of Devil's Town on the internet.

These specific natural formations are the result of an erosive process that lasted for at least two hundred thousand years, during which those formations evolved and passed through different stages of development. The Devil's Town rocks are andesitic volcanic and volcaniclastic rocks and have been protected since 1959. In 1995, the Decree of the Government of the Republic of Serbia proclaimed a site of National importance" and placed into the highest category of protection. A total area of 67 hectares is protected, although there is a requirement to increase the protected area to 1014 ha.

\subsection{Geological background}

The geology of the broader area is presented on the Basic Geological Map 1:100.000, sheets Kuršumlija and Podujevo (MALEŠEVIĆ et al., 1974; VUKANOVIĆ et al., 1975). The oldest rocks are Cambrian gneisses and subordinate Devonian metamorphosed limestone. Broad areas cover Cretaceous products, conglomerate and flysch sediments associated with members of the Jurassic ophiolite mélange (previously known as the "diabasechert formation” DIMITRIJEVIĆ \& DIMITRIJEVIĆ, 1974). The most dominant lithological units are products of Oligocene volcanism with a formation age of 32-28 Ma (KARAMATA et al., 1992; KOSTIĆ et al., 2017). These volcanic products are andesites and volcaniclastic rocks including lava flows, pyroclastic breccias, crystalline and lapilli tuffs (DIMITRIJEVIĆ \& DRAKULIĆ, 1958; DRAGIĆ et al., 2014). Andesite displays a porphyritic texture, and contains plagioclase (Fig.3a), amphibole-hornblende (Fig.3b), biotite (less frequently) and monoclinic and orthorhombic pyroxenes as phenocrysts. Accessory constituents are apatite and opaque minerals. Their uniform chemistry suggests uniform volcanism within the entire complex (JOVANOVIĆ et al., 1972). Negligible variations in chemistry could be a consequence of

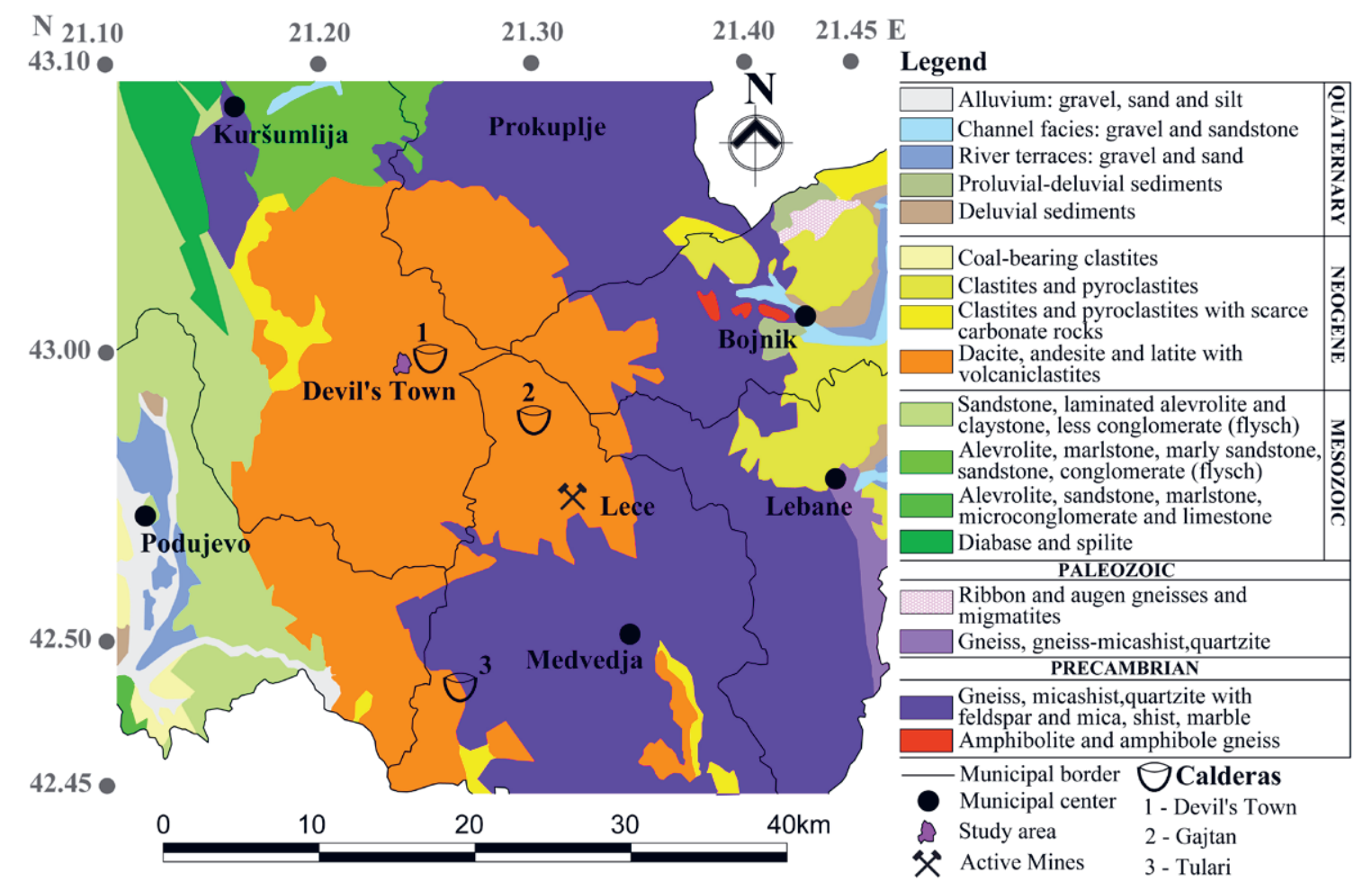

Figure 2. Geological map of research area. Source: Map processed by authors based on data of GEOLISS, 2020). 

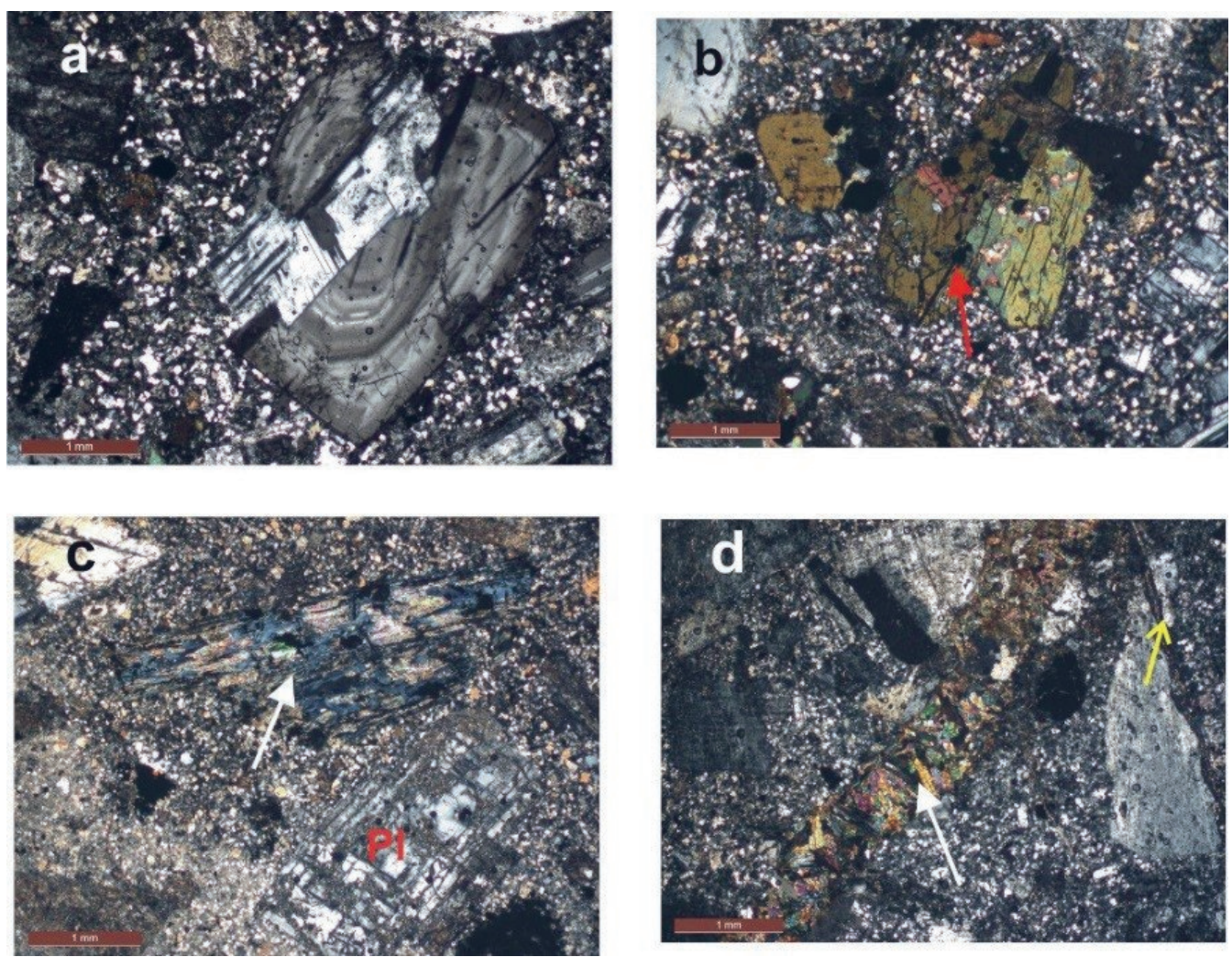

Figure 3. Microphotographs of porphyritic andesite: a) phenocryst of zoned plagioclase - andesine; b) phenocryst of hornblende (red arrow); c) bluish chlorite formed over amphibole (white arrow: pl-plagioclase); d) epidote vein, thick (white arrow) and thin one (yellow arrow) in hydrothermally altered sample.

minimal changes of steam pressure inside a volcanic vent or internal diffusion during peaceful phases as well as hydrothermal action and subsequent alteration (JOVANOVIĆ et al., 1972). Pyroclastic rocks, including some well-bonded ignimbritic types, comprise horizons from a few - $100 \mathrm{~m}$ thick. Hydrothermally altered rocks are most abundant in the area of interest occurring as reef zones due to their higher resistance (Fig. 3c, d). The most intensive hydrothermal process is silicification revealing the remarkable, several kilometers long zone of silicification known as the "quartzose-brecciated zones" (PEŠUT, 1976). At higher elevation, intense phyllic alteration occurs, which encompasses the mineralized rocks (DRAGIĆ et al., 2014). Hydrothermal alteration developed along favourable volcanic-tectonic and tectonic rupture systems (STAJEVIĆ, 2004). Fissures about $1 \mathrm{~km}$ in length prevail, although some exceed a few $\mathrm{km}$. In the same fracture zones precious minerals occur together with galena, sphalerite, pyrite and gold (e.g. the Rasovača, Vrtače, Kameno rebro and Bučumet deposit). Precious silicate minerals include amethyst, amethyst-agate, agate, fibrous chalcedony, granular quartz and relic opal, which display very heterogeneous colour varieties (MILADINOVIĆ et al., 2010). Although gemstone deposits became the subject of interest after World War II, on the basis of certain archaeological finds it is known that the amethyst and agate had been exploited by the Ancient Romans. Numerous poorly explored occurrences, mostly placer deposits (eluvial, deluvial, proluvial and alluvial), distributed outwith the volcanic complex, i.e. on its eastern rim also exist. Volcanic products affected by siliceous and/or siliceous-mineralized hydrothermal fluids were later exposed to further weathering and erosion along the already existing fissures.

Volcanoes in this area undoubtely exceeded $1000 \mathrm{~m}$ in height (Gajtan caldera in spite erosion and shortenning reaches approxi- mately $700 \mathrm{~m}$ a.s.1.). Devil's Town is the largest and most complex caldera with a diameter of about $25 \mathrm{~km}$. The best preserved parts are at Sokolovica (in the north) and at Markov Vis (in the south).

\subsection{Relief shaping}

Volcanism initially sculpted this area in the Palaeogene, i.e. Upper Oligocene (DIMITRIJEVIĆ \& DRAKULIĆ, 1958). According to JOVANOVIĆ et al. (1972) and VALJAREVIĆ et al. (2015) volcanic activity evolved throughout three phases:

1. Development of stratovolcanoes (emitting both tephra and viscous lava, building steep conical mounds),

2. Formation of calderas, and

3. Subsequent processes inside the calderas and consolidation of the entire complex.

1. Stratovolcanoes (complex, composite or gray volcanoes) are large, long-lived volcanoes, particularly those of andesitic composition that emit a combination of lava flows and tephra, building steep-sided volcanic cones. A growing lava dome might exceed $1000 \mathrm{~m}$ in height, as lava flows resist or slow down erosion and loss of tephra. The beautiful steep-sided cones of stratovolcanoes are among Earth's most picturesque sights (e.g. Mount Fuji in Japan, Mount Rainier and Mount St. Helen in Washington, former volcanoes in East Serbia etc.). The height of volcanoes in this area undoubtely exceeded 1000 $\mathrm{m}$ (as the Gajtan caldera is now, although eroded and shortened, nearly $700 \mathrm{~m}$ ), with a basal diameter greater than $30 \mathrm{~km}$. Stratovolcanoes are often transformed over time as calderas roughly circular basins, the diameter of which can vary between $1-25 \mathrm{~km}$, some of which are still preserved as relics. In general, a caldera develops by collapse after the partial or complete emptying of a magma chamber. The unsupported roof of the empty chambers sinks slowly under its own weight. 
2. Caldera dimensions exceeded the dimensions of the former volcanic cones. Pyroclastic rocks as well as lava flows in the relics of former stratovolcanoes generally dip towards the volcano periphery, if not affected by subsequent tectonic events. Devil's Town is, as mentioned above, within the volcanic complex of Lece, a sub-volcanic $\mathrm{Pb}-\mathrm{Zn}$ deposit, which consists of three large calderas: Gajtan, Devil's Town and Tulari. However, at present, a significantly larger number of smaller calderas and volcanic vents are being observed (SERAFIMOVSKI, 1990; DRAGIĆ et al., 2014). As a result of pronounced erosion accompanied by the effects of endogenic (volcanic) movements within the calderas. Their height can not be precisely determined. The Gajtan caldera is the oldest one with only the eastern part preserved at Petrova gora. The southern part was eroded, whereas the western and northern parts were destroyed during development of the Devil's Town caldera. The Tulari caldera is the smallest and the best preserved suggesting that it is the youngest one. It has a complex fabric with a recognizable northward migration of the centre of effusion. The youngest effusion centre is still preserved in the form of the neck (Braina) from where a radial dyke stretches towards the north. Devil's Town caldera with a diameter of about $25 \mathrm{~km}$ is the largest and most complex, consisting of three smaller calderas: Devil's Town, Ivan Kula and Kravari. Tectonic activity and faulting during the northward migration of its eastern part additionally destroyed and reworked it. The best preserved parts are at Sokolovica (in the north) and at Markov Vis (in the south). Their marginal parts are composed of pyroclastic rocks, while the internal parts (morphologically higher and closer to the inner caldera) are of alternating pyroclastic rocks and lava flows. The outer zone is marked with well sorted material, according to grain size. Tuffaceous sandstone and volcanic gravel overlie crystalline schists and Cretaceous flysch in the footwall. Volcanic breccias and agglomerates build the highest levels. The interior is composed of coarser volcanic products: agglomerates, breccias, volcanic bombs $(20-30 \mathrm{~cm}$ in diameter), and boulders reaching a few metres in size. Volcaniclastic rocks are represented by a mixture of coarse-grained blocks (from a few decimetres to a few metres in size) and fine-grained material explosively ejected from volcanoes. The pillars roofs are of andesite or dacite lava, which like umbrellas either protects them or slows down further erosion and destruction.

3. The presence of sinterized tuffs and younger lava flows in the Gajtan caldera, including repeated volcanic activity in the Tulare caldera, reflects the continuation of volcanic activity within the previously formed calderas. During the final volcanic phases, after consolidation of the magmatic masses, basal uplift in the form of domas took place enabling the development of radially distributed fissures through which hydrothermal solutions percolated. Hydrothermal solutions, meso- to epithermal, affected the host rocks which were subjected to physical and chemical weathering and erosion. These processes finally shaped this area. The stone formations were dissected into twenty metre thick layers of weathered delluvial material (i.e. debris flow) and their growth was enabled by the existence of "caps or roofs" of more resistent material (lava flows) (Fig. 4).

Similar forms have been noted in the high mountain ranges of the Andes and Alps (e.g. both sides of the Brenner pass, in
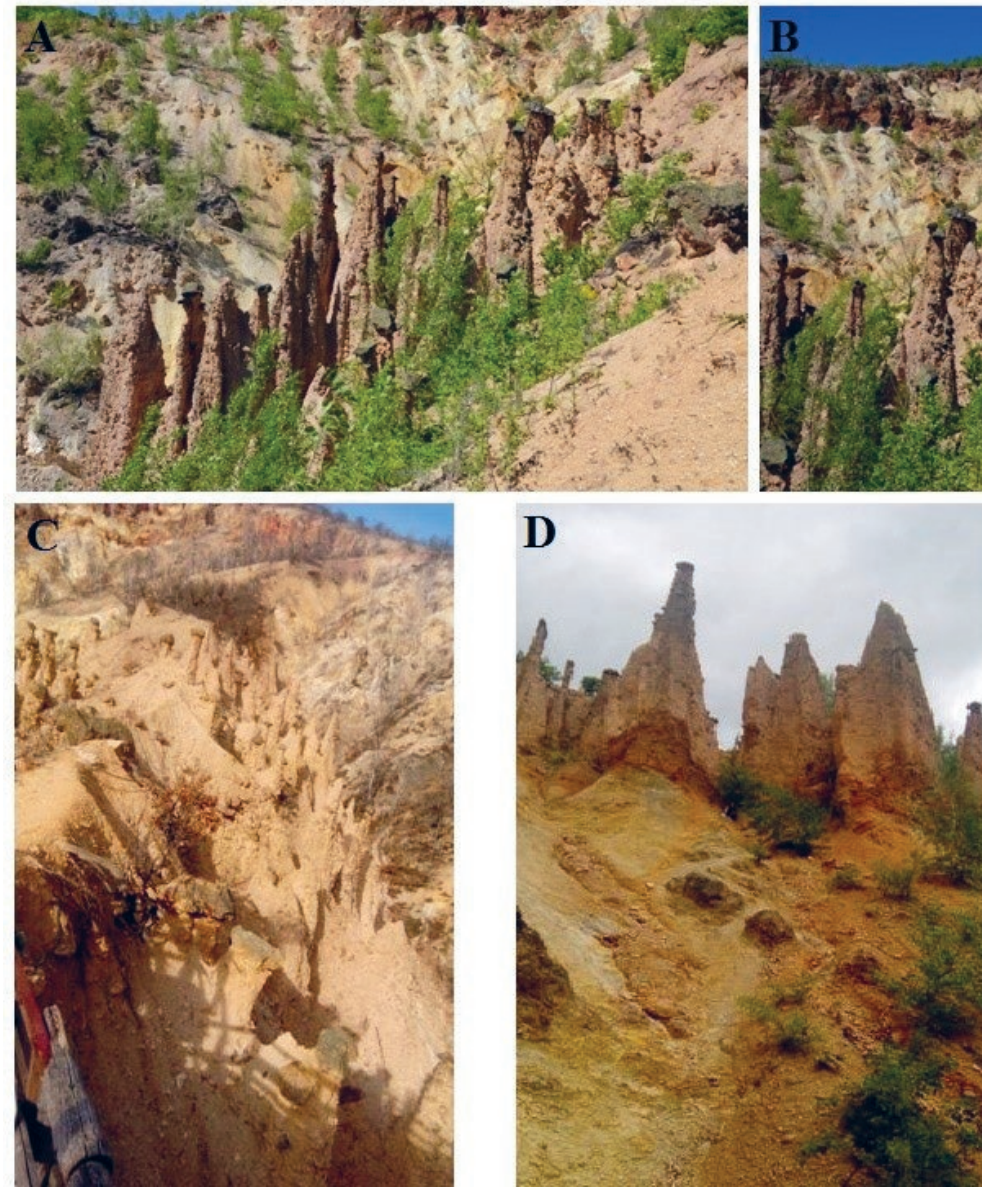
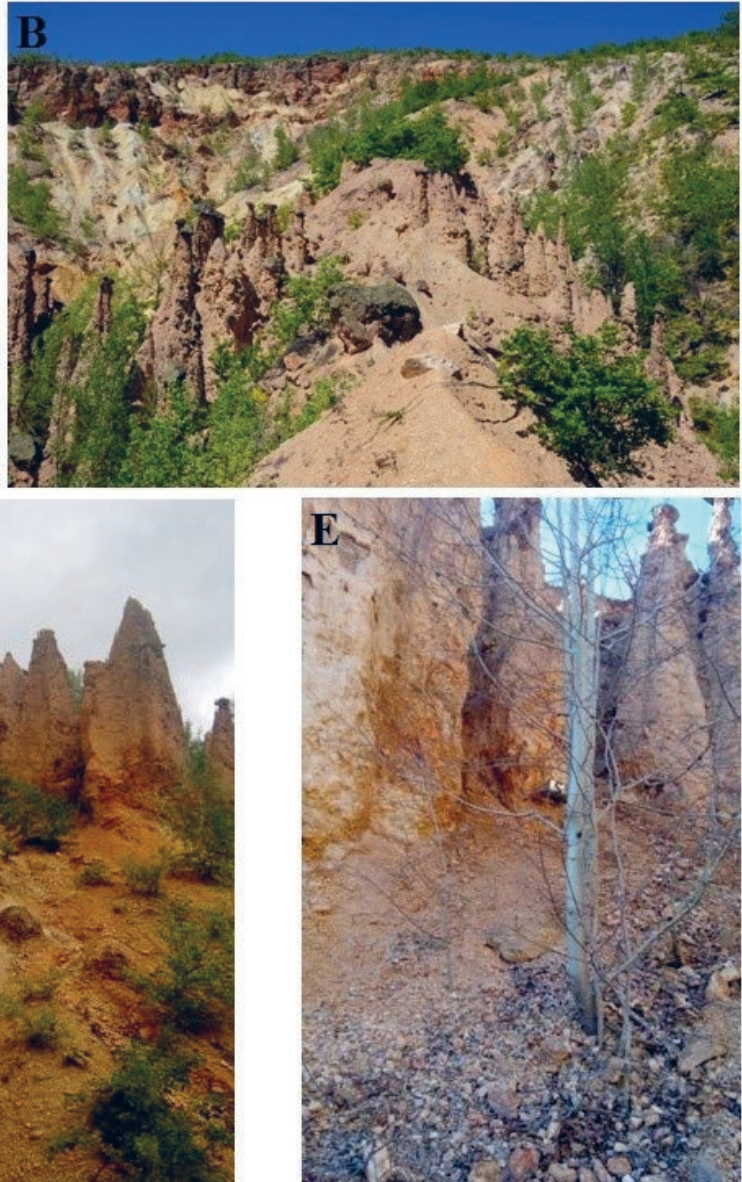

Figure 4. A - Devil's Town; B - The reef between Devil's Town and Hell's Gully; C - Hell's Gully; D - Earth pillars in Devil's Town; E - Earth pillars in Hell's Gully. 


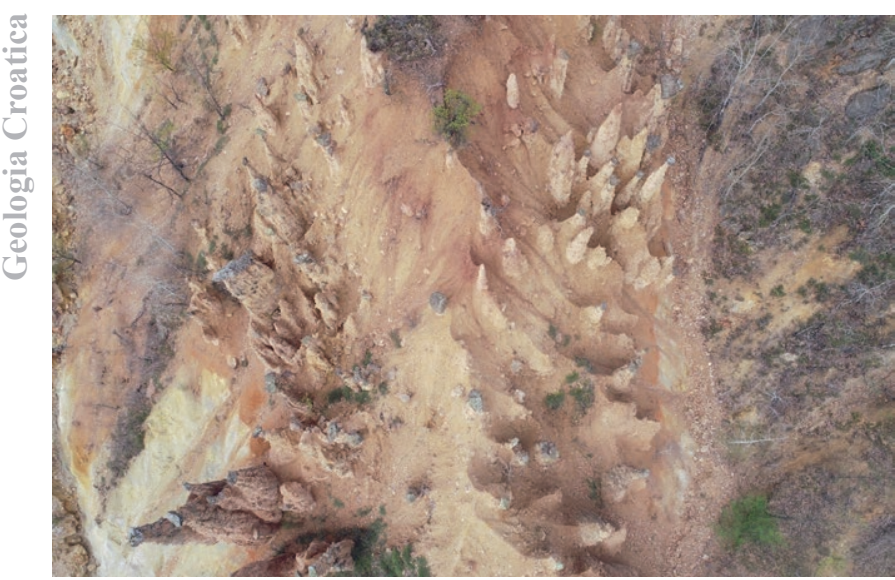

Figure 5. The bird's-eye view photograph of the Devil's Town.

Austria, Italy and France etc.), where they were formed through leaching of glacial (moraine) material. Spectacular forms in the Garden of the Gods (Illinois, USA) were formed within sediments (red and white sandstone, limestone and conglomerates of Carboniferous age, about 320 Ma old) that were deposited horizontally, but later have been tilted vertically and faulted by immense mountain building forces (SKINNER \& PORTER, 2000). In the Sahara desert, the Memuniat formation was created within the Ordovician sandstone. However, in Devil's Town, stone formations are more abundant, larger in dimensions and more resistant, providing a representative example of the diverse erosive action of water supported by lithological differences and rare hydrothermal occurrences (Fig. 5).
The wider area of Devil's Town is rich in ore (iron, aluminum, gold and silver), and demonstrates mines dating back to the 13th century and the arrival of German Saxon miners (Fig. 6). In fact, the Saxon miners restored mines and the ore-forming sites known from the Ancient and the Prehistoric ages. The nearby Neolithic site (5500 to 4700 B.C.) in the village of Pločnik, near Prokuplje, preserved a significant number of prehistoric metal-made weapons and copper tools. These artifacts suggest that this site was a centre of metallurgy in Europe dating back to 5500-4800 B.C., i.e. that the Copper Age started in Europe earlier than previously understood. It is also thought that the ore was obtained from an azurite and malachite deposit from the site in the vicinity of Toplica and Kosanica, as neither immediate locations of ore excavation nor slag residues resulting from smelting were discovered (ĆUZOVIĆ et al., 2004). Additionally, the remains of the medieval fortification constructed on the basement of the former Roman settlement of Hammeum (second half of 1st century), were discovered at Hisar hill (Prokuplje). This site is also under state protection and considered to be a monument of great cultural importance.

The entrances to the mine shafts are very narrow, which is characteristic of the castle mines. One of the three preserved mine shafts has been explored. Its entrance is expanded and its length is about $800 \mathrm{~m}$ (http://www.djavoljavaros.com/).

There are two rare hydrological phenomena in Devil's Town, related to the last phases of vulcanism. Extremely cold and acidic water (pH 1.5), highly mineralized (15 g / 1, most of Si, Al, Fe and S) with a hardness of about 21,050d springs in the upper part of the Devil's Gully. This spring is known as the "Devil's Water".
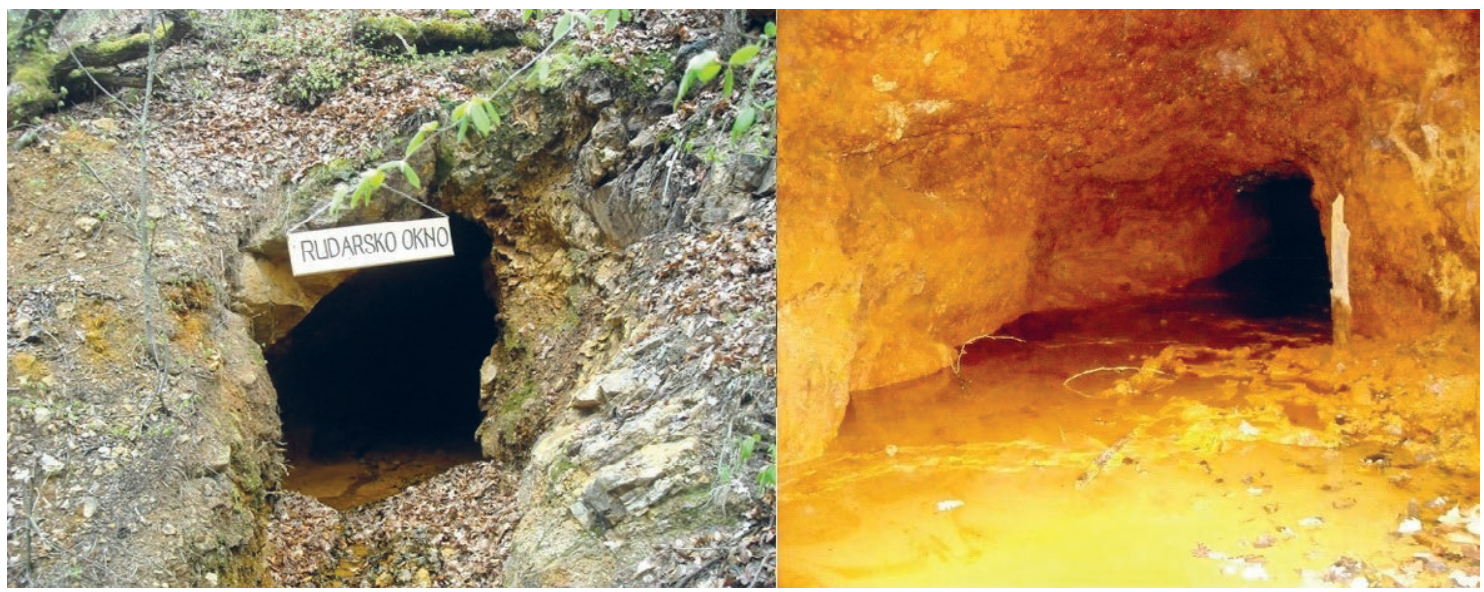

Figure 6. Investigated mining shaft in Devil's Town.
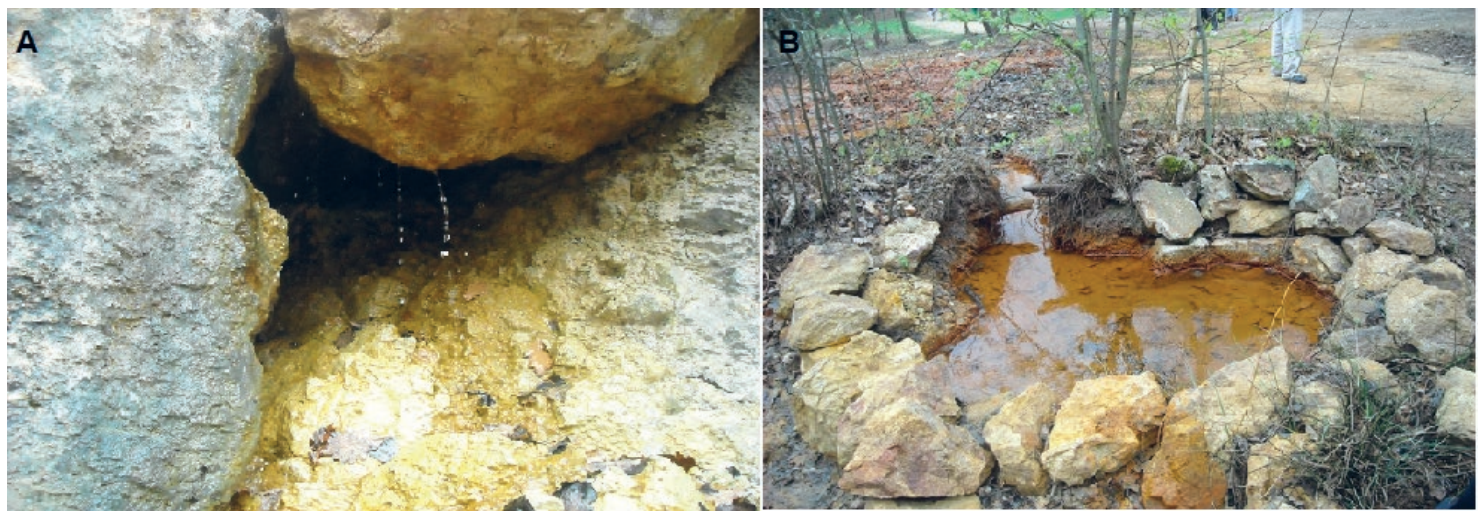

Figure 7. A- Devil's Water; B- Red Spring. 
One litre of water contains over $1.5 \mathrm{~g}$ of metal (Al, Fe, K, Cu, Ni) and $2.63 \mathrm{~g}$ of sulfur. Due to its very low $\mathrm{pH}$, this water is also a good solvent, suggesting that some amounts of $\mathrm{Al}$, Fe and $\mathrm{K}$ were probably extracted from the surrounding rocks. Water in the spring called "Crveno Vrelo (the Red Spring)" (to the right side of the Yellow Stream, about $400 \mathrm{~m}$ from the previously mentioned spring) is less acidic (ph 4.0) and iron-rich (198.8 mg / 1). The oxidized iron along with substances which came from the surrounding rocks led to changes in the water properties in the stream revealing its name "Žuti Potok (Yellow Stream)". The waters of both springs have no healing properties, but they are a natural poison to the living world (PROTIĆ, 1995; http://www. izjz-nis.org.rs/; SREĆKOVIĆ-BATOĆANIN, D. et al., 2010) (Fig. 7).

\subsection{Examples of similar localities in the Balkans}

Geolocalities in structure and origin similar to Devil's Town $\left(\mathrm{GS}_{1}\right)$ in the Balkan area include: the Sand Pyramids $\left(\mathrm{GS}_{2}\right)$ in Bosnia and Herzegovina and Stob $\left(\mathrm{GS}_{3}\right)$ and the Melnik Earth pyramids $\left(\mathrm{GS}_{4}\right)$ in Bulgaria (Fig. 8).

Small peaks called "pyramids" appear in the southeasternmost part of the macro region Bosansko Sredogorje near the village of Daničići (location Šljivovice, $9 \mathrm{~km}$ from Foča in Bosnia and Herzegovina). Similar landmarks are noted in the vicinity, too. These forms consist of alternating Pliocene clastites - conglomerate, gravel and sand derived in eluvial relief from the former Miocene basin under the triggered action of proluvial and gravitational processes during the Quaternary. The sand pyramids represent a classic example of selective denudation due to the existence of more resistant layers of Pliocene conglomerates in the hanging wall (LEPIRICA, 2013). Continual erosion facilitates their persistent growth.

Sculptured sand columns rise from a broad base and narrow towards the top revealing amazing geomorphological phenomena within the area. These sand pyramids were protected by a declaration of the Commission to Preserve the National Monuments of Bosnia and Herzegovina in 1959. At present the Institution is revising the inventory of localities that have been protected up to 1992. Due to its outstanding importance, specific protection measures are suggested for this locality. It needs to be evaluated in the sense of tourism, bearing in mind that it is commonly compared to the Devil's Town in Serbia (LEPIRICA, 2010).

The Stob pyramids, known as hoodoos, are located between the western foothills of Rila Mountain and the eastern localities of Kulski rid and Tsarkvishteto near the village of Stob, about 5 $\mathrm{km}$ from the city of Kocherinovo (Kyustendil Province) in Bulgaria. This site is very popular, in many ways like the Melnik pyramids on the slopes of Pirin Mountain, (Bulgaria) and Devil's Town in Serbia. The site is insufficiently explored and information concerning it remains far behind similar localities elewhere in the world (e.g. the Wheeler geological area in the USA and Cappadocia in Turkey). These erosive landmarks, up to $12 \mathrm{~m}$ in height with a stony top, up to $120 \mathrm{~cm}$ in diameter, occupy an area of about 7.4 ha at 600 to $750 \mathrm{~m}$ a.s.l. The pyramids are composed of weakly bonded Neogene-Quaternary sandstones and conglomerates deposited within the last 1-2 Ma on the slope in a lacustrine environment.

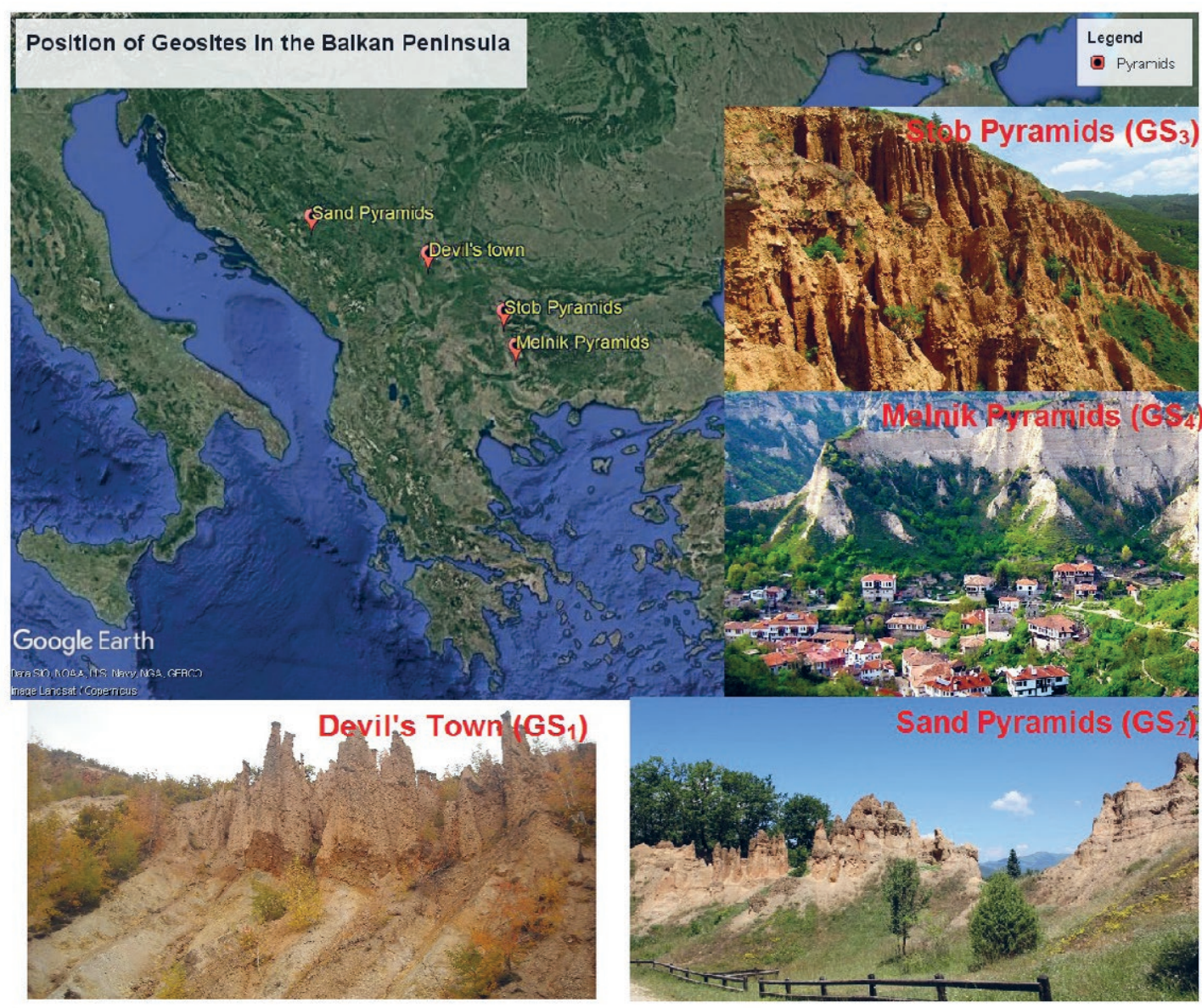

Figure 8. Position of geosites on the Balkan Peninsula. 
Table 1. The structure of the Geosite Assessment Model (GAM) (VUJIČĆ et al., 2011).

Indicators/Sub-indicators

Description

Main values (MV)

Scientific/Educational value (VSE)

1. Rarity

2. Representativeness

Number of nearby identical sites

Didactic and exemplary characteristics of the site due to its own quality and general configuration

3. Knowledge on geoscientific issues

4. Level of interpretation

Number of published papers in journals, thesis, presentations and other publications

Level of interpretive possibilities on geological and geomorphologic processes, phenomena and shapes and level of scientific knowledge

Scenic/Aesthetic (VSA)

5. Viewpoints

6. Surface

7. Surrounding landscape and nature

8. Environmental fitting of sites

Protection (VPr)

9. Current condition

10. Protection level

11. Vulnerability

12. Suitable number of visitors

Additional values (AV)

Functional values (VFn)

13. Accessibility

14. Additional natural values

15. Additional anthropogenic values

16. Vicinity of emissive centers

17. Vicinity of important road network

18. Additional functional values

Touristic values (VTr)

19. Promotion

20. Organized visits

21. Vicinity of visitors centers

22. Interpretative panels

23. Number of visitors

24. Tourism infrastructure

Number of viewpoints accessible for pedestrians. Each must be situated less than $1 \mathrm{~km}$ from the site.

Whole surface of the site. Each site is considered in quantitative relation to other sites Panoramic view quality, presence of water and vegetation, absence of human-induced deterioration, vicinity of urban area, etc.

Level of contrast to the nature, contrast of colours, appearance of shapes, etc.

Current state of geosite

Protection by local or regional groups, national government, international organizations, etc.

Level of vulnerability of the geosite

Supposed number of tourists on the site at the same time, according to surface area, vulnerability and current state of geosite

25. Tour guide service

26. Hostelry service

27. Restaurant service

Grades (0.00-1.00)

0.00

2.

3.

Common

None

4. None

None

Regional

Region

Low

ocal publications

Moderate level of

processes but hard to explain to non-experts

5. None

1

6. Small

7.

8.

- Low

9.

Unfitting

Totally damaged (as a result Highly damaged (as a of human activities) result of natural processes)

10.

None Local

11.

Irreversible (with possibility High (could be easily of total loss) damaged)

12. 0

13. Inaccessible

0 to 10 Low (on foot with special equipment and expert guide tours)

\begin{tabular}{llll}
\hline 14. & 1 & 2 to
\end{tabular}

15. None

1

Possibilities for approaching the site

Number of additional natural values in the radius of $5 \mathrm{~km}$ (geosites also included)

Number of additional anthropogenic values in the radius of $5 \mathrm{~km}$

Closeness of emissive centers

Closeness of important road networks in the radius of $20 \mathrm{~km}$

Parking lots, gas stations, mechanics, etc.

Level and number of promotional resources

Annual number of organized visits to the geosite

Closeness of visitor center to the geosite

Interpretative characteristics of text and graphics, material quality, size, fitting to

surroundings, etc

Annual number of visitors

Level of additional infrastructure for tourist (pedestrian pathways, resting places, garbage cans, toilets etc.)

If exists, expertise level, knowledge of foreign language(s), interpretative skills, etc Hostelry service close to geosite

Restaurant service close to geosite

50

0.50

National

Moderate

Regional publications

0.75

International

High

but easy to explain to common visito non-experts

2 to 3

4 to 6

Medium

Medium

High

Neutral

Medium damaged (with

essential geomorphologic

features preserved)

Regional

Medium (could be damaged

by natural processes or

human activities)

10 to 20

The only occurence

Highest

International publications

Good example of processes

and easy to explain to most

visitors

More than 6

Large

Utmost

Fitting

Medium (by bicycle and

other means of man-powered transport)

2 to $3 \quad 4$ to $6 \quad$ More than 6

2 to 3

4 to 6

More than 6

Low (could be damaged only by human activities)

20 to 50

More than 50

Utmost (by bus) 


\begin{tabular}{|c|c|c|c|c|c|}
\hline 16. & More than $100 \mathrm{~km}$ & 100 to $50 \mathrm{~km}$ & 50 to $25 \mathrm{~km}$ & 25 to $5 \mathrm{~km}$ & Less than $5 \mathrm{~km}$ \\
\hline 17. & None & Local & Regional & National & International \\
\hline 18. & None & Low & Medium & High & Utmost \\
\hline 19. & None & Local & Regional & National & International \\
\hline 20. & None & Less than 12 per year & 12 to 24 per year & 24 to 48 per year & More than 48 year per \\
\hline 21. & More than 50 km & 50 to $20 \mathrm{~km}$ & 20 to $5 \mathrm{~km}$ & 5 to $1 \mathrm{~km}$ & Less than $1 \mathrm{~km}$ \\
\hline 22. & None & Low quality & Medium quality & High quality & Utmost quality \\
\hline 23. & None & Low (less than 5000) & Medium (5001 to 10000$)$ & High (10 001 to 100000$)$ & Utmost (more than 100000 ) \\
\hline 24. & None & Low & Medium & High & Utmost \\
\hline 25. & None & Low & Medium & High & Utmost \\
\hline 26. & More than 50 km & $25-50 \mathrm{~km}$ & $10-25 \mathrm{~km}$ & $5-10 \mathrm{~km}$ & Less than $5 \mathrm{~km}$ \\
\hline 27. & More than $25 \mathrm{~km}$ & $10-25 \mathrm{~km}$ & $10-5 \mathrm{~km}$ & $1-5 \mathrm{~km}$ & Less than $1 \mathrm{~km}$ \\
\hline
\end{tabular}

The Stob Earth Pyramids were declared a natural landmark in 1964. Their formation, evolution and destruction are taking place in repeated stages driven by groundwater, temperature inversion and wind. At the immediate site, two evolutionary stages could be recognized. The site is easily accessible to visitors via designated pathways and viewpoints, which offer a panoramic view over the whole geosite and nearby settlements (Stob, Porominovo, Barakovo, Kocherinovo, Rila). In the immediate vicinity of Stob village, there are also ancient ruins that should be evaluated in terms of tourism (https://www.andrey-andreev.com/en/ stob-pyramids-bulgaria/).

The Melnik pyramids are considered to be the most interesting natural wonder in Bulgaria, as well as on the Balkan Peninsula. These pyramids are similar to those at Stob, but are much greater in size and spatial distribution. The Melnik pyramids are located on the southwestern slope of Pirin Mountain at about 180 $\mathrm{km}$ south of Sofia, in the Blagoevgrad Province and the municipality of Sandanski. The exact sites are Melnik, Gorna Sushitsa, Karlanovo, Rozhen and Sugarevo. This geosite has been protected since 1960 (enlarged and redeclared in 1978) over an area of 1165.6 ha. Rock formations resembling pyramids are located from 350 - $850 \mathrm{~m}$ a.s.l. Their variable colours and heights offer an amazing, very attractive image. The increasing number of visitors from all over the world required a number of buildings and recreation centres to be built in Melnik.

The Melnik region consists of grayish-white Pliocene sand, mixed with clay layers. It was deposited at the bottom of a shallow lake 3-5 Ma ago. Folding caused by the collision of continental plates led to the formation of mountain ranges, such as Pirin, Ograzden and Belasica. The lake water flowed to the south and discharged into the Aegean Sea. In the newly formed valley, terrigenous material was brought by mountain rivers and streams leading to the formation of about 500-600 $\mathrm{m}$ of alluvial deposits of weakly cemented and reddish sedimentary rocks. Over the next thousands of years, sediments accumulated up to $120 \mathrm{~m}$ thick, nourished from the Pirin range by mountain rivers and streams. In the variously shaped valleys the pyramid formation was additionally supported by wind action and temperature inversion.

The Melnik pyramids are of noteworthy shapes and of various sizes that are subjected to changes due to the decomposition and decay of plants, such as deciduous trees, bushes and grasses that thrive there. The most visited pyramids are those located near the Rozhen Monastery. They are easily accessible by constructed pathways from the city of Melnik to the Rozhen monastery. The other attractive group of pyramids is in the village of Karlanovo. Although there are only four pyramids, they look impressive exceeding $100 \mathrm{~m}$ in height, having slopes barren of vegetation and with flattened peaks. The stony caps have the same protective role against erosion, as in the previously mentioned localities. The small city of Melnik, additionally contributes to the attractiveness for tourists. Renowned for its authentic architecture from the renaissance era it is declared an architectural reserve. Additional anthropogenic tourist values include: the Kordopulov House - a large house from the Bulgarian national revival period, Wine Museum, Rozhen monastery - the biggest Orthodox Church in the Pirin Mountain area.

\subsection{Methodology}

Andesite samples were optically analyzed using a petrographic polarized microscope for transmitted light (Leica DMLSP), which is connected to a Leica DFC290 HD camera over the program LAS V4.

\subsubsection{M-GAM model}

Previous geosite assessment models involved geosite assessment criteria adjusted for tourists (PRALONG, 2005; SERRANO \& GONZÁLEZ-TRUEBA, 2005; HOSE, 2007; PEREIRA et al., 2007; ZOUROS, 2007; REYNARD, 2008; REYNARD, 2009; REYNARD et al., 2016; REYNARD \& BRILHA, 2018) and experts (BRUSCHI \& CENDRERO, 2005; CORATZA \& GIUSTI, 2005; HOSE, 2007; WHITE \& WAKELIN-KING, 2014). VUJIČIĆ et al. (2011) proposed a model for the evaluation of geolocalities (GAM) based on the experts' opinion, whereas TOMIĆ \& BOŽIĆ (2014) modified the GAM model into the M-GAM model, and based it on both the opinions of experts and visitors.

This study includes the values of experts for all 27 sub-indicators in GAM (Table 1) along with the tourist values (Im) (Table 2), which have already been presented by BOŽIĆ \& TOMIĆ (2015). In the original GAM model two important indicators are included: Main Values and Additional Values, and then divided into 12 and 15 indicators respectively, each scored between 0 and 1 . This kind of model is made according to two general kinds of values: main - mostly generated by the geosite's natural characteristics; and additional - mostly generated by modifications for its use by visitors. The Main Values are conducted by three groups of indicators: scientific/educational (VSE), scenic/aesthetical values (VSA) and protection (VPr) while the Additional Values are divided into two groups of indicators, functional (VFn) and touristic values (VTr). The Main and Additional Values are presented in Table 1. 
The GAM is defined as a simple equation, a sum of 12 subindicators of the Main Values, and 15 sub-indicators of the Additional Values which are graded from 0 to 1 :

$$
G A M=M V+A V
$$

where $M V$ and $A V$ represent the symbols for the Main and Additional Values. We derive these two equations, because Main and Additional Values consist of three or two groups of sub-indicators,

$$
\begin{gathered}
M V=V S E+V S A+V P r \\
A V=V F n+V T r
\end{gathered}
$$

Now that we know that each group of indicators consists of several sub-indicators, equations (2) and (3) can be written as follows:

$M V=V S E+V S A+V P r=\sum_{i=1}^{12} \operatorname{SIM} V_{i}$, where $0 \leq S I M V_{i} \leq 1$

$$
A V=V F n+V T r=\sum_{j=1}^{15} \operatorname{SIA} V_{i}, \text { where } 0 \leq S I A V_{i} \leq 1
$$

Here, $S I M V_{i}$ and $S I A V_{j}$ represents 12 sub-indicators of the Main Values $(i=1 \ldots, 12)$ and 15 subindicators $(j=1, \ldots, 15)$ of the Additional Values.

A matrix of Main ( $\mathrm{X}$ axes) and Additional Values ( $\mathrm{Y}$ axes) is created according to the results. The matrix is divided into nine fields represented by $Z(i, j)$, (i,j=1,2,3). Depending on the final score, each geosite will fit into a certain field. For example, if a geosite's Main Values are 7 and additional are 4, the geosite will fit into the $Z_{21}$ field (Figure 9).

High precision and applicability at several geolocalities (TOMIĆ et al., 2015; JONIĆ, 2018; ANTIĆ et al., 2019; VUKOVIĆ \& ANTIĆ, 2019; TOMIĆ et al., 2020) were the main reasons to introduce the importance factor ( $\mathrm{Im}$ ) that has been presented by BOŽIĆ \& TOMIĆ (2015). The importance factor (Im) is the mean

\begin{tabular}{|c|c|c|c|c|c|c|c|c|c|}
\hline \multirow{2}{*}{ Main Indicators / Sub-indicators } & \multicolumn{4}{|c|}{ (GAM) Expert's estimation (0-1) } & \multirow{2}{*}{ Im } & \multicolumn{4}{|c|}{ (M-GAM) Total estimation } \\
\hline & $\mathrm{GS}_{1}$ & $\mathrm{GS}_{2}$ & $\mathrm{GS}_{3}$ & $\mathrm{GS}_{4}$ & & $\mathrm{GS}_{1}$ & $\mathrm{GS}_{2}$ & $\mathrm{GS}_{3}$ & $\mathrm{GS}_{4}$ \\
\hline I Scientific/Educational values (VSE) & & & & & & 2.12 & 1.58 & 1.47 & 1,88 \\
\hline 1. Rarity & 0.75 & 0.50 & 0.25 & 0.25 & 0.89 & 0.67 & 0.45 & 0.22 & 0.22 \\
\hline 2. Representativeness & 1.00 & 0.75 & 0.75 & 1.00 & 0.79 & 0.79 & 0.59 & 0.59 & 0.79 \\
\hline 3. Knowledge on geoscientific issues & 0.50 & 0.25 & 0.50 & 0.50 & 0.45 & 0.23 & 0.11 & 0.23 & 0.23 \\
\hline 4. Level of interpretation & 0.50 & 0.50 & 0.50 & 0.75 & 0.85 & 0.43 & 0.43 & 0.43 & 0.64 \\
\hline II Scenic/Aesthetic (VSA) & & & & & & 2.22 & 1.72 & 2.79 & 2.96 \\
\hline 5. Viewpoints & 0.75 & 0.50 & 1.00 & 1.00 & 0.79 & 0.59 & 0.40 & 0.79 & 0.79 \\
\hline 6. Surface & 0.75 & 0.50 & 1.00 & 1.00 & 0.54 & 0.41 & 0.27 & 0.54 & 0.54 \\
\hline 7. Surrounding landscape and nature & 0.75 & 0.75 & 1.00 & 1.00 & 0.95 & 0.71 & 0.71 & 0.95 & 0.95 \\
\hline 8. Environmental fitting of sites & 0.75 & 0.50 & 0.75 & 1.00 & 0.68 & 0.51 & 0.34 & 0.51 & 0.68 \\
\hline III Protection (VPr) & & & & & & 1.8 & 1.31 & 1.90 & 2.09 \\
\hline 9. Current condition & 0.75 & 0.75 & 0.75 & 0.75 & 0.83 & 0.62 & 0.62 & 0.62 & 0.62 \\
\hline 10. Protection level & 0.75 & 0.25 & 0.75 & 1.00 & 0.76 & 0.57 & 0.19 & 0.57 & 0.76 \\
\hline 11. Vulnerability & 0.50 & 0.50 & 0.50 & 0.50 & 0.58 & 0.29 & 0.29 & 0.29 & 0.29 \\
\hline 12. Suitable number of visitors & 0.75 & 0.50 & 0.75 & 1.00 & 0.42 & 0.32 & 0.21 & 0.42 & 0.42 \\
\hline IV Functional values (VFn) & & & & & & 1.66 & 2.28 & 2.89 & 3.24 \\
\hline 13. Accessibility & 0.75 & 0.75 & 0.75 & 0.75 & 0.75 & 0.56 & 0.56 & 0.56 & 0.56 \\
\hline 14. Additional natural values & 0.25 & 0.50 & 0.75 & 1.00 & 0.71 & 0.18 & 0.36 & 0.53 & 0.71 \\
\hline 15. Additional anthropogenic values & 0.25 & 0.50 & 0.75 & 1.00 & 0.70 & 0.18 & 0.35 & 0.53 & 0.70 \\
\hline 16. Vicinity of emissive centers & 0.25 & 0.50 & 0.75 & 0.75 & 0.48 & 0.12 & 0.24 & 0.36 & 0.36 \\
\hline 17. Vicinity of important road network & 0.75 & 0.75 & 0.75 & 0.75 & 0.62 & 0.47 & 0.47 & 0.47 & 0.47 \\
\hline 18. Additional functional values & 0.25 & 0.50 & 0.75 & 0.75 & 0.59 & 0.15 & 0.30 & 0.44 & 0.44 \\
\hline V Touristic values (VTr) & & & & & & 3.9 & 1.66 & 4.67 & 5.78 \\
\hline 19. Promotion & 1.00 & 0.25 & 0.75 & 0.75 & 0.85 & 0.85 & 0.21 & 0.64 & 0.64 \\
\hline 20. Organized visits & 1.00 & 0.25 & 0.75 & 1.00 & 0.56 & 0.56 & 0.14 & 0.42 & 0.56 \\
\hline 21. Vicinity of visitors centers & 0.25 & 0.25 & 0.50 & 0.75 & 0.87 & 0.22 & 0.22 & 0.44 & 0.65 \\
\hline 22. Interpretative panels & 0.00 & 0.25 & 0.75 & 0.75 & 0.81 & 0 & 0.20 & 0.61 & 0.61 \\
\hline 23. Number of visitors & 0.75 & 0.25 & 0.50 & 1.00 & 0.43 & 0.32 & 0.11 & 0.22 & 0.43 \\
\hline 24. Tourism infrastructure & 0.75 & 0.25 & 0.75 & 1.00 & 0.73 & 0.55 & 0.18 & 0.55 & 0.73 \\
\hline 25. Tour guide service & 0.50 & 0.25 & 0.75 & 0.75 & 0.87 & 0.44 & 0.22 & 0.65 & 0.65 \\
\hline 26. Hostelry service & 0.50 & 0.25 & 0.75 & 1.00 & 0.73 & 0.37 & 0.18 & 0.55 & 0.73 \\
\hline 27. Restaurant service & 0.75 & 0.25 & 0.75 & 1.00 & 0.78 & 0.59 & 0.20 & 0.59 & 0.78 \\
\hline
\end{tabular}
value for each sub-indicator given by tourists. A few more papers concerning the use of M-GAM (PĂL \& ALBERT, 2018; ANTIĆ

Table 2. Values given by experts and visitors for each sub-indicators in the GAM model.

$\mathrm{GS}_{1}$ - Devil's Town (Serbia), GS 2 - Sand pyramids (Bosnia and Herzegovina), $\mathrm{GS}_{3}$ - Stob pyramids (Bulgaria), GS 4 - Melnik pyramids (Bulgaria) Im - importance factor. 
et al., 2020; BRATIĆ et al., 2020; TOMIĆ et al., 2021) have been published in the most recent few months.

The importance factor ( $\mathrm{Im})$ is defined, as:

$$
\operatorname{Im}=\frac{\sum_{k=1}^{k} I v_{k}}{K}
$$

Where $I v_{k}$ is the assessment/score of one visitor for each sub-indicator and $K$ is the total number of visitors. Note that the $I m$ parameter can have any value in the range from 0.00 to 1.00. Finally, the modified GAM equation is defined in the following form:

$$
\begin{gathered}
M-G A M=M V * A V \\
M V=\sum_{i=1}^{n} I m_{i}^{*} M V_{i} \\
A V=\sum_{i=1}^{n} I m_{j}^{*} A V_{j}
\end{gathered}
$$

As it can be seen from the $M-G A M$ equation, the value of the importance factor (Im), which is rated by visitors (for each sub-indicator separately) is multiplied with the value given by experts (also separately for each sub-indicator). This is done for each subindicator in the model. Therefore, the values of $M$-GAM sub-indicators are always less or equal to the $G A M$ values (Table 2).

\section{RESULTS AND DISCUSSION}

The unique geomorphological phenomenon in Serbia, the Devil's Town, $\left(\mathrm{GS}_{1}\right)$, was being considered with respect to three similar localities on the Balkan Peninsula, the Sand pyramids $\left(\mathrm{GS}_{2}\right)$ in Bosnia and Herzegovina, and the Stob $\left(\mathrm{GS}_{3}\right)$ and Melnik pyramids $\left(\mathrm{GS}_{4}\right)$ in Bulgaria. Geosites were evaluated using the above mentioned methodology (M-GAM). Values for the Main indicators and sub-indicators are given in Table 2, whereas the final results of these values are presented in Table 3 and Figure 9.

According to the results obtained, Devil's Town $\left(\mathrm{GS}_{1}\right)$ displays the highest scientific/educative value of the analyzed geosites, being particularly emphasized by its representativeness. This could be explained by the high didactic and educational characteristics of the locality itself. The Melnik pyramids $\left(\mathrm{GS}_{4}\right)$ are also known by their representativeness due to features of the geosite. However, the Sand pyramids $\left(\mathrm{GS}_{2}\right)$ and Stob pyramids $\left(\mathrm{GS}_{3}\right)$ geosites are of significantly lower scientific value. The knowledge on their geoscientific issues has the lowest value within the analyzed sub-indicators of scientific value of all of the analyzed geosites. The lowest number of publications relates to the Sand pyramids $\left(\mathrm{GS}_{2}\right)$, while articles for the rest of geosites

\begin{tabular}{|c|c|c|c|c|c|}
\hline \multicolumn{6}{|l|}{ Values } \\
\hline & \multirow{2}{*}{$\begin{array}{r}\text { Main } \\
V S E+V S A+V P r\end{array}$} & \multicolumn{4}{|c|}{ Additional } \\
\hline & & $\Sigma$ & $\mathrm{VFn}+\mathrm{VTr}$ & $\Sigma$ & Field \\
\hline $\mathrm{GS}_{1}$ & $2.12+2.22+1.80$ & 6.14 & $1.66+3.90$ & 5.56 & $Z_{22}$ \\
\hline $\mathrm{GS}_{2}$ & $1.58+1.72+1.31$ & 4.61 & $2.28+1.66$ & 3.94 & $\mathrm{Z}_{21}$ \\
\hline $\mathrm{GS}_{3}$ & $1.47+2.79+1.90$ & 6.16 & $2.89+4.67$ & 7.56 & $\mathrm{Z}_{22}$ \\
\hline $\mathrm{GS}_{4}$ & $1,88+2,96+2,09$ & 6,93 & $3,24+5,78$ & 9,02 & $Z_{22}$ \\
\hline
\end{tabular}
were commonly published in local publications, less commonly in regional and national journals. The Stob $\left(\mathrm{GS}_{3}\right)$ and Melnik

Table 3. Overall ranking of the analyzed geosites using M-GAM.

$\mathrm{GS}_{1}$ - Devil's Town (Serbia), $\mathrm{GS}_{2}$ - Sand pyramids (Bosnia and Herzegovina), $\mathrm{GS}_{3}-$ Stob pyramids (Bulgaria), $G_{4}-$ Melnik pyramids (Bulgaria) pyramids $\left(\mathrm{GS}_{4}\right)$ also record low values for rarities, as both geosites are in Bulgaria in the circled area of $100 \mathrm{~km}$.

Concerning scenic/aesthetic values, the Melnik pyramids $\left(\mathrm{GS}_{4}\right)$ exhibit the highest values due to the amazing landscape and beautiful natural scenery in the vicinity: a number of designated viewpoints, contrasting colours and shapes, as well as the overall appearance of the geosite. The Stob pyramids $\left(\mathrm{GS}_{3}\right)$ geosite has a lower aesthetic value in spite of the breathtaking panoramic view, plenty of easy accessible pathways and viewpoints and contrasting colour with the surrounding nature. The geosite Devil's Town $\left(\mathrm{GS}_{1}\right)$ is of exceptional scenic/aesthetic value regarding nature and its vicinity. The lowest value is ascribed to its spatial distribution in comparison with the area of other geosites $\left(\mathrm{GS}_{4}\right.$ and $\left.\mathrm{GS}_{3}\right)$. The lowest aesthetic value within the analyzed geosites relates to the Sand pyramids $\left(\mathrm{GS}_{2}\right)$ due to a smaller area and a lesser number of landscape areas.

Considering protection, which is a very important indicator of the main values, only small differences were noted between these four geosites. The lowest level of protection goes to the Sand pyramids (1.31). Some higher values were exhibited at Devil's Town (1.80) and the Stob pyramids (1.90). The geolocality Melnik is reasonably the highest ranked (2.09) as it has been under protection much longer than the other three geosites. The biggest differences among the sub-indicators were recorded for the level of protection and accommodation capacities. The largest areas are occupied by the geosites Melnik $\left(\mathrm{GS}_{4}\right)$ and Stob $\left(\mathrm{GS}_{3}\right)$, hence their values are the highest. In contrast, the geolocality Sand pyramids $\left(\mathrm{GS}_{2}\right)$ covers the smallest area and thus displays the lowest value.

Considering the additional values, particularly the natural and anthropogenic ones, the best results were indicated by the geosite Melnik $\left(\mathrm{GS}_{4}\right)$. Being well-known for its natural values and surrounding settlements of rich cultural-historical heritage, Melnik $\left(\mathrm{GS}_{4}\right)$ displays the highest additional, natural and anthropogenic values. Stob pyramids $\left(\mathrm{GS}_{3}\right)$ are also surrounded by plenty of natural and anthropogenic values, whereas the remaining two geosites $\left(\mathrm{GS}_{1}\right.$ and $\left.\mathrm{GS}_{2}\right)$ are less worthy due to their distance from other attractive tourist destinations. The vicinity of emissive centers is among the functional values of the lowest value in all of the analyzed geosites. However, some higher values

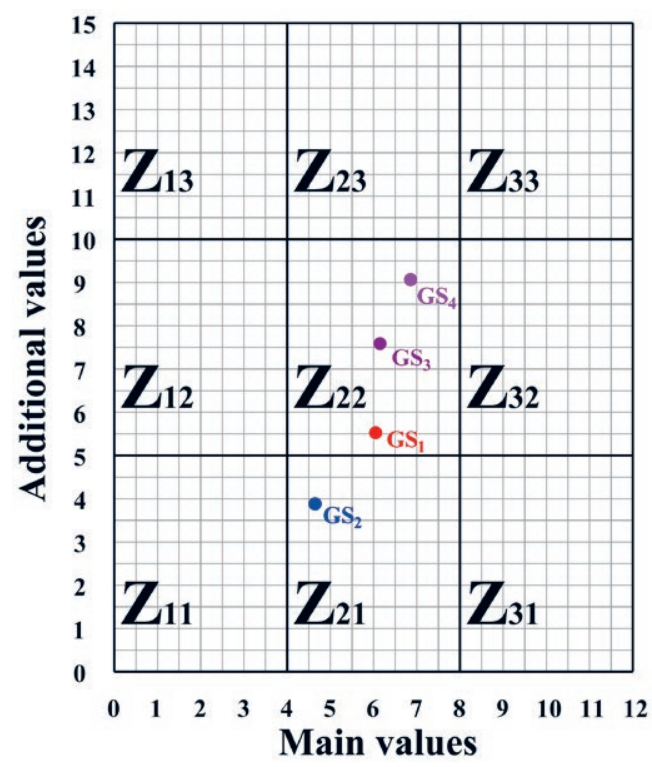

Figure 9. Position of evaluated geosites in M-GAM matrix. 
were displayed by geosites Melnik and Stob in comparison with Devil's Town and the Sand pyramids. The important emissive centre in Melnik $\left(\mathrm{GS}_{4}\right)$ is the city of Sandanski, approximately $20 \mathrm{~km}$ distant. This city in Blagoevgrad Province is the third biggest city and one of the famous spas in Bulgaria. The nearest emissive centre to the Stob pyramids $\left(\mathrm{GS}_{3}\right)$ is Blagoevgrad, at about $15 \mathrm{~km}$. Sarajevo, some $60 \mathrm{~km}$ away, is the nearest emissive centre to the Sand pyramids $\left(\mathrm{GS}_{2}\right)$. Finally, the cities of Niš and Kruševac, being about $90 \mathrm{~km}$ distant, are the nearest to Devil's Town.

Melnik $\left(\mathrm{GS}_{4}\right)$, has the highest touristic value among the analyzed geosites, being particularly noteworthy for its touristic infrastructure among the sub-indicators (designed long pedestrian pathways, resting places at viewpoints), hostelry and restaurant services placed next to the pyramids. However, the number of visitors is not in accordance with promotional activities, remaining insufficient and at a low level. Slightly lower touristic value displays Stob $\left(\mathrm{GS}_{3}\right)$, whereas the geosite Devil's Town $\left(\mathrm{GS}_{1}\right)$ remains far behind Melnik and Stob due to insufficient interpretative panels, the distance from visitor centers and hostelry services. The advantage of Devil's Town in comparison to the other analyzed localities is the significant level of promotional activities. The lowest touristic values exhibited by the Sand pyramids $\left(\mathrm{GS}_{2}\right)$ having low values of all the sub-indicators.

According to the final results for all the analyzed geosites, given in table 3 , are the determined positions in M-GAM matrix (Fig. 9).

On the basis of the final results (Table 3 ) it could be concluded that in the future attention should be paid to the additional values at geosites $\mathrm{GS}_{1}$ and $\mathrm{GS}_{2}$. Sub-indicators obtained low values due to the distance from broadcasting centres as well as visitor centres, and the geosite lacked accommodation services, interpretative boards and additional functional values. In addition to these elements, there is a high level of sensitivity of geosites to natural and human interferences.

In spite of all the geo-tourist values that the site of the Devil's Town has, the manager of AD "Planinka" from Kuršumlija must be ready for the development of competition in the wider area, while at the same time tightening the criteria for assessing the load on the environment. This company must improve the quality of the resulting solutions, innovate procedures and learn to continue the improvement of activities and successful achievement in competitive surroundings (SÜTÖOVÁ et al., 2018).

\section{SUMMARY AND CONCLUSION}

It could be concluded that the highest differences within the analyzed geolocalities display touristic values that rely on tourism development in the country where the geosite is located and on tourist valorization of geosites. Sub-indicators from this group, such as promotion, organized visits, interpretative panels, tourism infrastructure, guidelines, accommodation and restaurant services, could be easily changed and improved by human activity and investment in tourism development.

According to the position of the evaluated geosites in the GEM matrix, along with the final results presented in Tables 2 and 3, the absolute domination of Melnik $\left(\mathrm{GS}_{4}\right)$ among the analyzed geosites is apparent. However, the inevitable upgrading of additional values for a better position in the matrix is necessary.

The Sand pyramids $\left(\mathrm{GS}_{2}\right)$ occupy the lowest position in the matrix, having significant main values, but unfortunately displaying the lowest additional values. This suggests the high potential of the Sand pyramids and direct progress in geotourism development with the improvement of additional values, particularly touristic ones.

Devil's Town $\left(\mathrm{GS}_{1}\right)$ is most similar to the Stob pyramids $\left(\mathrm{GS}_{2}\right)$ regarding the main values. Concerning the additional values, both geosites belong to the moderate level. Nevertheless, the Stob pyramids occupy a higher position in the matrix due to higher additional values. Thus, the appropriate increase of functional and touristic values would contribute to a better position in matrix.

Furthermore, the management of each geosite should focus on a specific market segment shaping and directing the development of the site towards the specific needs and preferences of tourism segments. Therefore, this research indicates what is important for the different segments when visiting a geosite so it can be used as a framework for tourism planning. Having said this, the management of each geosite should develop a tourism strategy depending on whether it intends to become a destination for mass tourism or to attract smaller specific tourism segments such as pure geotourists and thus base the development of a geosite according to their needs and preferences. In order to strike the right balance between the offer for general tourists and pure geotourists in the future, we should keep tourism development in a sustainable form, taking care of the protection of geosites and reducing the negative impact of tourism, which can be triggered by mass tourist visits.

\section{ACKNOWLEDGMENT}

We are very grateful to the enterprise "Planinka" in Kuršumlija for providing official records and for the efforts they have made to conduct surveys of visitors (tourists).

\section{REFERENCES}

ANTIĆ, A. \& TOMIĆ, N. (2017): Geoheritage and geotourism potential of the Homolje area (eastern Serbia).-Acta Geoturistica, 8/2, 67-78. doi: 10.1515/agta-2017-0007

ANTIĆ, A., TOMIĆ, N. \& MARKOVIĆ, S. (2019): Karst geoheritage and geotourism potential in the Pek River lower basin (eastern Serbia).- Geographica Pannonica, 23/1, 32-46. doi: 10.5937/gp23-20463

ANTIĆ, A., TOMIĆ, N. \& MARKOVIĆ, S. (2020): Karst-Based Geotourism in Eastern Carphatian Serbia: Exploration and Evaluation of Natural Stone Bridges.- Geoconservation Research, 3/2, 62-80. doi: 10.30486/gcr.2020.1903486.1023

BELIJ, S. (2007): Geodiverzitet i geonasleđe - savremeni trend razvoja geomorfologije u svetu i kod nas.- Zbornik Geografskog intituta Jovan Cvijić, 57, 65-70. doi: 10.2298/IJGI0757065B

BELIJ, S. (2008): Geodiverzitet i geonasleđe u razvoju geomorfologije i zaštiti prirode.Zaštita prirode, 58/1-2, 5-14.

BELIJ, S. (2009): Stanje i zaštita geodiverziteta i objekata geonasleđa u Srbiji.- Zaštita prirode, 60/1-2, 349-358.

BOŠKOV, J., KOTRLA, S., JOVANOVIĆ, M., TOMIĆ, N., LUKIĆ, T. \& RVOVIĆ, I. (2015): Application of the Preliminary Geosite Assessment Model (GAM): The Case of the Bela Crkva Municipality (Vojvodina, North Serbia).- Geographica Pannonica,19/3, 146-152.

BOŽIĆ, S. \& TOMIĆ, N. (2015): Canyons and gorges as potential geotourism destinations in Serbia: comparative analysis from two perspectives - general geotourists' and pure geotourists'.- Open Geoscence., 7/1, 531-546. doi: 10.1515/geo-20150040

BRAGA, J.C. (Coord.) (2002): Propuesta de estrategia andaluza para la conservación de la geodiversidad [Andalucia strategy proposal for the conservation of geodiversity - in Spanish]. - Junta de Andalucía, Consejería de Medio Ambiente, 105 p.

BRATIĆ, M., MARJANOVIĆ, M., RADIVOJEVIĆ, A.R. \& PAVLOVIĆ, M. (2020): M-GAM method in function of tourism potential assessment: Case study of the Sokobanja basin in eastern Serbia.- Open Geosciences, 12, 1468-1485. doi: doi: 10.1515/geo-2020-0116

BRILHA, J. (2005): Património geológico e geoconservação--A conservação da natureza na suavertente geológica. Viseu: Palimage.

BRUSCHI, V.M. \& CENDRERO, A. (2005): Geosite evaluation. Can we measure intangible values?- Il Quaternario, 18/1, 293-306. 
BUREK, C.V. \& PROSSER, C.D. (2008): The history of geoconservation: an introduction.- In: BUREK, C.V. \& PROSSER, C.D. (eds.): The History of Geoconservation. Geological Society, London, 1-5. doi: 10.1144/SP300.1

CGIAR Consortium for Spatial Information. SRTM 90m Digital Elevation Data. 2017. Retrieved from: http://srtm.csi.cgiar.org/ (accessed: 22 February 2017).

CORATZA, P. \& GIUSTI, C. (2005): Methodological proposal for the assessment of the scientific quality of geomorphosites.- Il Quaternario, 18/1, 307-313.

ĆUZOVIĆ, M., STAJIĆ, D. \& OSTOJIĆ, M. (2004): From Unhealthy Rock to Black Gold.- JP PEU, Resavica, $315 \mathrm{p}$

DIMITRIJEVIĆ, M. \& DRAKULIĆ, N. (1958): Kristalasti škriljci Jablanice.-Zbornik Rudarsko-geološkog fakulteta, 6, 1-32.

DIMITRIJEVIĆ, M.D. \& DIMITRIJEVIĆ, M.N. (1974): O genezi ’Dijabaz-rožnačke formacije“.--Geološki glasnik, 7, 333-345.

DJAVOLJA VAROŠ: http://www.djavoljavaros.com/ (accessed: 28 February 2017)

DJUROVIĆ, P. \& MIJOVIĆ, D. (2006): Geoheritage of Serbia-Representative of its total geodiversity.- Zbornik Radova Geografskog Fakulteta u Beogradu, 54, 5-18. (in Serbian).

DOWLING, R.K. (2011): Geotourism's Global Growth.- Geoheritage, 3/1, 1-13. doi: 10.1007/s12371-010-0024-7

DRAGIĆ, D., MISKOVIC, A., HART, C., TOSDAL, R., FOX, Ph. \& GLISIC, S. (2014): Spatial and temporal relations between epithermal and porphyry style mineralization in the Lece Magmatic Complex, Serbia.- Poster in SEG Conference 2014, Keystone, CO, USA.

GEOLISS (Geological Information System of Serbia; Web publishing by GeolISS team Faculty of Mining and Geology, University of Belgrade) (2020): Basic geological map. Belgrade: Ministry of Energy, Development and Environmental Protection of Republic of Serbia. Retrieved from http://geoliss.mre.gov.rs (accessed: 05 September 2020).

GRANDGIRARD, V. \& SZEPESI, A. (1997): Geomorphology and management of natural heritage (the protection of the geotopes, a new task in geomorphology).Noosfera, 3, 59-65.

GRAY, M. (2008): Geodiversity: developing the paradigm.- Proceedings of the Geologists' Association, 119/3-4, 287-298. doi: 10.1016/S0016-7878(08)80307-0

GRAY, M. (2013): Geodiversity: Valuing and Conserving Abiotic Nature.- Wiley-Blackwell. Chichester, U.K.

HOSE, T.A. (2000): European Geotourism - Geological Interpretation and Geoconservation Promotion for Tourists.- In: BARRETINO, D., WIMBLEDON, W.P. \& GALLEGO, E. (eds.): Geological Heritage: Its Conservation and Management. Madrid: Instituto Tecnologico Geominero de Espana, 127-146.

HOSE, T.A. (2005a): Geo-Tourism - Appreciating the deep side of landscapes.- In: NOVELLI, M. (ed.): Niche Tourism: Contemporary issues, trends and cases. Elsevier Science, Oxford, 27-37.

HOSE, T.A. (2005b): Geotourism and Interpretation.- In: DOWLING, R.K. \& NEWSOME, D. (eds.): Geotourism. Elsevier, Oxford, 221-241. doi: 10.1016/B978-07506-6215-4.50020-8

HOSE, T.A. (2007): Geotourism in Almeria province, southeast Spain.- Tourism, 55, 259-276.

HOSE, T.A. (2008): The Genesis of Geotourism and its Management Implications.- In: Abstracts Volume, 4th International Conference, GEOTOUR 2008, Geotourism and Mining Heritage, Krakow.

HOSE, T.A., MARKOVIĆ, S.B., KOMAC, B. \& ZORN, M. (2011): Geotourism - a short introduction.- Acta geographica Slovenica, 51/2, 339-342. doi: 10.3986/ AGS51301

HOSE, T.A. \& VASILJEVIĆ, Đ.A. (2012): Defining the Nature and Purpose of Modern Geotourism with Particular Reference to the United Kingdom and South-East Europe.- Geoheritage 4/1-2, 25-43. doi: 10.1007/s12371-011-0050-0

INSTITUTE OF PUBLIC HEALTH OF NIS: (http://www.izjz-nis.org.rs/) (accessed: 4 December 2010)

JONIĆ, V. (2018): Comparative analysis of Devil s town and Bryce canyon geosites by applying the modified geosite assessment model (M-GAM).- Researches Reviews of the Department of Geography, Tourism and Hotel Management, 47/2, 113-125.

JOVANOVIĆ, M., KARAJIČIĆ, Lj., KARAMATA, S. \& VUKANOVIĆ, M. (1972): Novi pogledi na razvoj vulkanizma u području leckog andezitskog kompleksa.Geol. anali balk. pol., 37/2, 165-177.

JOYCE, E.B. (2006): Geomorphological Sites and the New Geotourism in Australia.Geological Society of Australia. Melbourne. (http://web.earthsci.unimelb.edu.au/ Joyce/heritage/GeotourismReviewebj.htm)

KOSTIĆ, B., ŠARIĆ, K., CVETKOVIĆ, V., KRSTEKANIĆ, N., PANTELIĆ, N. \& BOSIC, D. (2017): A reinterpretation of the geological map of northwestern part of Lece Volcanic Complex.-- In: 13th Workshop on Alpine Geological Studies, Zlatibor Mts., Belgrade, University of Belgrade-Faculty of Mining and Geology.

KARAMATA, S., STOJANOV, R., SERAFIMOVSKI, T. et al. (1992): Tertiary magmatism in the Dinarides of the Vardar zone and the Serbo-Macedonian Massif.-Geologica Macedonica, 6/1, 127-186.

LEPIRICA, A. (2010): Prirodni uslovi i mogućnosti za razvoj turizma u mezoregiji Gornje Podrinje.- Zbornik radova PMF, 7, 57-79.
LEPIRICA, A. (2013): Geomorfologija Bosne i Hercegovine.- Biblioteka University book, Sarajevo Publishing, $208 \mathrm{p}$

LJEŠEVIĆ, M.A. (2002): Geodiverzitet kao uslov i iskaz životne sredine.- Zbornik radova PMF, 50, 17-32

MALAŠEVIĆ, M., VUKANOVIĆ, M., BRKOVIĆ, T., OBRADINOVIĆ, Z., KARAJIČIĆ, LJ., STANISAVLJEVIĆ, R., DIMITRIJEVIĆ, M. \& UROŠEVIĆ, M. (1974): Basic Geological Map 1:100.000, Kuršumlija K 34-31, Savezni geološki zavod, Belgrade.

MILADINOVIĆ, Z., ILIĆ, M. \& SIMIĆ, V. (2010): Gemstone deposits of Lece volcanic complex (South Serbia).- In: XIX Congress of Carpathian-Balkan Geological Association, Thessaloniki, Greece, 23-26th September, Akademichno Izdatelstvo Prof. Marin Drinov, Bulgarian Academy of Sciences Sofia. Geologica Balcanica, 39/1-2, 253-254

MIJOVIĆ, D. \& MILJANOVIĆ, D. (1999): Naučni i obrazovni kriterijumi evaluacije geonasleđa uplaniranju zaštite prirodnih predela.- Zaštita prirode 51/2, 133-139.

MIJOVIĆ, D. (2002): Menadžment objekata geo-nasleđa u Srbiji - put ka geoturizmu.Zaštita prirode, 53/2, 135-142.

MIJOVIĆ, D., RUNDIĆ, LJ. \& MILOVANOVIĆ, D. (2005): Zaštita geonasleđa u Srbiji i pravci razvoja.- In: Zbornik radova Drugog naučnog skupa o geonasleđu Srbije. Zavod za zaštitu prirode Srbije, Beograd, 17-21.

NEWSOME, D. \& DOWLING, R.K. (2006): The Scope and Nature of Geotourism.- In: DOWLING, R.K. \& NEWSOME, D. (eds.): Geotourism, Elsevier, Oxford, 3-25. doi: 10.1016/B978-0-7506-6215-4.50009-9

NEWSOME, D. \& DOWLING, R.K. (2010): Geotourism: the tourism of geology and landscape.- Goodfellow Publishers, Oxford. doi: 10.23912/978-1-906884-09-3-21

NOJKOVIĆ, S. \& MIJOVIĆ, D. (1998): Zaštita geo-nasleđa u Srbiji nekad i sad.-Zaštita prirode, $50,439-442$.

PĂL, M. \& ALBERT, G. (2018): Comparison geotourism assessment models: An experiment in Bakony-Balaton UNSECO Global Geopark, Hungary.-Acta Geoturistica, 9, 1-13.

PANIZZA, M. \& PIACENTE, S. (2003): Geomorfologia culturale.- Piatogora Editrice, Bologna, $350 \mathrm{p}$.

PEREIRA, P., PEREIRA, D. \& CAETANO ALVES, M.I. (2007): Geomorphosite assessment in Montesinho Natural Park (Portugal).- Geographica Helvetica, 62/3, 159-168. doi: 10.5194/gh-62-159-2007

PEŠUT, D. (1976): Geology, tectonics and metallogeny of Lece massif.- Rasprave Zavoda za geološka i geofizička istraživanja, 14, 1-59. (in Serbian, English summary).

PRALONG, J.P. (2005): A method for assessing the tourist potential and use of geomorphological sites.- Géomorphologie. Relief, processus, environnement, 11/3, 189-196. doi: 10.4000/geomorphologie.350

PRALONG, J.P. \& REYNARD, E. (2005): A proposal for a geomorphological sites classification depending on their tourist value.-Il Quaternario, 18/1 (volume speciale), 313-319.

PRALONG, J.P. (2006): Géotourisme et utilisation de sites naturels d'intérêt pour les sciences de la Terre. Les régions de Crans-Montana- Sierre (Valais, Alpes suisses) et Chamonix-Mont-Blanc (Haute-Savoie, Alpes françaises).- Travaux et Recherches n 32, Lausanne, Institutde Géographie, 224 p.

PROTIĆ, D. (1995): Mineral and thermal waters of Serbia.- Geoinstitute, special editions, 17, Belgrade, 77. (in Serbian)

REIS, R.P. \& HENRIQUES, M.H. (2009): Approaching an integrated qualification and evaluation system for geological heritage.- Geoheritage, 1/1, 1-10. doi: 10.1007/ s12371-009-0002-0

REYNARD, E. (2008): Scientific Research and Tourist Promotion of Geomorphological Heritage.- Geografia Fisica e Dinamica Quaternaria, 31/2, 225-230.

REYNARD, E. (2009): The assessment of geomorphosites.- In: REYNARD, E., CORATZA, P. \& REGOLINI-BISSIG, G. (eds): Geomorphosites. Pfeil Verlag, München, 63-72.

REYNARD, E., PERRET, A., BUSSARD, J., GRANGIER, L. \& MARTIN, S. (2016): Integrated Approach for the Inventory and Management of Geomorphological Heritage at the Regional Scale.- Geoheritage, 8, 43-60. doi: 10.1007/s12371-0150153-0

REYNARD, E. \& BRILHA, J. (2018): Geoheritage: Assessment, Protection, and Management.- Elsevier, Amsterdam, $482 \mathrm{p}$.

RISTIĆ, D., VUKOIČIĆ, D., NIKOLIĆ, M., DRAGOJLOVIĆ, J. \& MILENTIJEVIĆ, N. (2018): Prirodni resursi u funkciji razvoja zelenog turizma na području opštine Kuršumlija.- Ecologica, 25/92, 787-793.

ROCHA, J., BRILHA, J. \& HENRIQUES, M.H. (2014): Assessment of the geological heritage of Cape Mondego natural monument (Central Portugal).- Proceedings of the Geologists' Association, 125/1, 107-113. doi: 10.1016/j.pgeola.2013.04.005

SADRY, B.N. (2009): Fundamentals of Geotourism: with special emphasis on Iran.Samt publisher, Tehran, $220 \mathrm{p}$.

SCHMIDT, S.M., BERNOULLI, D., FÜGENSCHUH, B., MATENCO, L., SCHEFER, S., SCHUSTER, R., TISCHLER, M. \& USTASZEWSKI, K. (2008): The AlpineCarpathian-Dinaridic orogenic system: correlation and evolution of tectonic units.Swiss Journal of Geosciences, 101/1, 139-183. doi: 10.1007/s00015-008-1247-3 
SERAFIMOVSKI, T. (1990): Metallogeny of the Lece-Chalkidiki Zone.-Unpub. Ph.D. Thesis. University of Štip, Macedonia, 380 p. (in Macedonian)

SERRANO, E. \& GONZÁLEZ-TRUEBA, J.J. (2005): Assessment of geomorphosites in natural protected areas: the Picos de Europa National Park (Spain).- Géomorphologie. Formes, processus, environnement, 11/3, 197-208. doi: 10.4000/geomorphologie. 364

SKINNER, B.J. \& PORTER, S.C. (2000): The Dynamic Earth: An Introduction to Physical Geology, 4th Edition.- American Museum of Natural History, New York; John Wiley \& Sons, $575 \mathrm{p}$.

SÜTÖOVÁ, A., ZGODAVOVÁ, K. \& LAJCZYKOVÁ, M. (2018): Quality and Effectiveness Evaluation of the Geological Services Using CEDAC Method.- Acta Montanistica Slovaca, 23/1, 18-25.

SREĆKOVIĆ-BATOĆANIN, D., VUKOIČIĆ, D., PAPOVIĆ, O., MILOVANOVIĆ, D., KIĆOVIĆ, D. \& ĐEKIĆ, T. (2010): Devil's City-history of development and touristic potentials.- In: Proceedings of the International Symposium GEOECOLOGY-XXI CENTURY, GEOECO, Žabljak-Nikšić, 21-24 September, 257-268. (in Serbian, with English abstract)

STAJEVIĆ, B. (2004): Geochemical haloes of gold in the Lece ore field (southern Serbia).- Annales Géologiques de la Péninsule Balkanique, 65 (2002-2003), 93-99. doi: 10.2298/GABP0301093S

STANKOVIĆ, S.M. (2004): Turistička valorizacija geomorfoloških objekata geo-nasleđa Srbije.- Glasnik Srpskog geografskog društva, 84/1, 79-88.

TIČAR, J., TOMIĆ, N., VALJEVAC, B.M., ZORN, M., MARKOVIĆ, B.S. \& GAVRILOV, B.M. (2018): Speleotourism in Slovenia: balancing between mass tourism and geoheritage protection.- Open Geoscience, 10/1, 344-357. doi: 10.1515/geo-2018-0027

TOMIĆ, N. (2011): The potential of Lazar Canyon (Serbia) as a geotourism destination: inventory and evaluation.- Geographica Pannonica, 15/3, 103-112.

TOMIĆ, N. \& BOŽIĆ, S. (2014): A modified Geosite Assessment Model (M-GAM) and its Application on the Lazar Canyon area (Serbia).- International Journal of Environmental Research, 8/4, 1041-1052.

TOMIĆ, N., MARKOVIĆ, B.S., KORAĆ, M., MRĐIĆ, N., HOSE, A.T., VASILJEVIĆ, A.Đ., JOVIČIĆ, M. \& GAVRILOV, B.M. (2015): Exposing mammoths: From loess research discovery to public palaeontological park.- Quaternary International, 372/22, 142-150. doi: 10.1016/j.quaint.2014.12.026

TOMIĆ, N., MARKOVIĆ, S., ANTIĆ, A. \& TEŠIĆ, D. (2020): Exploring the potential for geotourism development in the Danube region of Serbia.- International Journal of Geoheritage and Parks, 8/2, 123-139.

TOMIĆ, N. \& KOŠIĆ, K. (2020): Developing the Spa Assessment Model (SAM) and its application on the Kopaonik-Jastrebac spa zone (Serbia).- Tourism Management Perspectives, 36, 100753. doi: 10.1016/j.tmp.2020.100753
TOMIĆ, N., SEPEHRIANNASAB, B., MARKOVIĆ, S.B., HAO, Q. \& LOBO, H.A.S. (2021): Exploring the Preferences of Iranian Geotourists: Case Study of Shadows Canyon and Canyon of Jinns.- Sustainability, 13/2, 798. d o i : $10.3390 /$ su13020798

TOSDAL, R.M. (2012): U-Pb SHRIMP-RG ages and trace element geochemistry of the Kiseljak and Yellow Creek porphyry Cu-Au prospects, Southern Serbia.- Dunav Resources doo internal report, $21 \mathrm{p}$.

VALJAREVIĆ, A., SREĆKOVIĆ-BATOĆANIN, D., ŽIVKOVIĆ, D. \& PERIĆ, D. (2015): GIS analysis of dissipation time of landscape in the Devil's city (Serbia).Acta Montanistica Slovaca, 20/2, 148-155.

VALJAREVIĆ, A., VUKOIČIĆ, D. \& VALJAREVIĆ, D. (2017): Evaluation of the tourist potential and natural attractivity of the Lukovska Spa.- Tourism Management Perspectives, 22, 7-16. doi: 10.1016/j.tmp.2016.12.004

VASILJEVIĆ, DJ.A., MARKOVIĆ, S.B., HOSE, T.A., SMALLEY, I., O'HARADHAND, K., BASARIN, B., LUKIC, T. \& VUJIČIC, M.D. (2011): Loess towards (geo) tourism - proposed application onloess in Vojvodina region (north Serbia).Acta geographica Slovenica, 51/3, 391-406.

VASILJEVIĆ, DJ.A. (2015): Geodiverzitet i geonasleđe Vojvodine u funkciji zaštite i turizma. Doktorska disertacija.- Departman za geografiju, turizam i hotelijerstvo, Prirodno-matematički fakultet, Univerzitet u Novom Sadu.

VUJIČIĆ, M.D., VASILJEVIĆ, D.A., MARKOVIĆ, S.B., HOSE, T.A., LUKIĆ, T., HADŽIĆ, O. \& JANIĆEVIĆ, S. (2011): Preliminary geosite assessment model (GAM) and its application on Fruška Gora Mountain, potential geotourism destination of Serbia.- Acta Geographica Slovenica, 51/2, 361-377. doi: 10.3986/ AGS51303

VUKANOVIĆ, M., DIMITRIJEVIĆ, M., DIMITRIJEVIĆ, M., KARAJIČIĆ, LJ., RAJČEVIĆ, D., NAVALA, M., UROŠEVIĆ, M., MALEŠEVIĆ, M., TRIFUNOVIĆ, S., SERDAR, R. \& ATIN, B. (1975): Basic Geological Map 1:100.000, sheet Podujevo K 34-43, Savezni geološki zavod, Belgrade.

VUKOIČIĆ, D., MILOSAVLJEVIĆ, S., VALJAREVIĆ, A., NIKOLIĆ, M. \& SREĆKOVIĆ-BATOĆANIN, D. (2018): The evaluation of geosites in the territory of National Park „Kopaonik“ (Serbia).- Open Geoscience, 10, 618-633. doi: 10.1515/geo-2018-0049

VUKOVIĆ, S. \& ANTIĆ, A. (2019): Speleological Approach for Geotourism Development in Zlatibor County (West Serbia).- Turizam, 23/1, 53-68. doi: 10.5937/turizam23-21325

WHITE, S. \& WAKELIN-KING, G.A. (2014): Earth sciences comparative matrix: a comparative method for geoheritage assessment.- Geographical research, 52/2, 168-181. doi: $10.1111 / 1745-5871.12062$

ZOUROS, N.C. (2007): Geomorphosite assessment and management in protected areas of Greece. The case of the Lesvos island coastal geomorphosites.- Geographica Helvetica, 62/3, 169-180. doi: 10.5194/gh-62-169-2007 